\title{
POSTALES, VIAJE Y TURISMO: LA EXPERIENCIA DE UNA VIAJERA ECUATORIANA A INICIOS DEL SIGLO XX
}

\author{
POSTCARDS, TRAVELLING AND TOURISM: THE EXPERIENCE OF AN \\ ECUADORIAN TRAVELLER AT THE BEGINNING OF THE 20th CENTURY
}

María Ángela Cifuentes Guerra* Universidad Diego Portales, Santiago, Chile

\begin{abstract}
RESUMEN: Como medio de comunicación, de intercambio epistolar o como objeto estimado por coleccionistas y viajeros, la tarjeta postal ilustrada guarda gran importancia dentro de la historia social y cultural, además de la riqueza de una cultura visual en torno a sus representaciones y apreciaciones. A través del análisis de la correspondencia sostenida durante principios del siglo XX entre una viajera de Ecuador, dentro de sus diversos desplazamientos por algunos lugares de América Latina y Europa, y sus destinatarios, este artículo explora las prácticas de comunicación epistolar por medio de la postal y, con ello, los diferentes usos dados en torno a la experiencia de viaje, a los modos de ver, transmitir e interactuar. La relación entre lo visual y lo textual resulta, así, el punto central para un estudio interpretativo.
\end{abstract}

PALABRAS CLAVE: postal, usos, apropiación, experiencia de viaje, mirada turística.

ABSTRACT: As a means of communication, for correspondence or as a beloved item of collectors and travellers, the illustrated postcard has an importance to social and cultural history, and, with its representations and assessments, is also a rich source of visual culture. Through the analysis of the correspondence between an Ecuadorian traveller, in her diverse movements to places in Latin America and Europe, and her correspondents, at the beginning of the 20th century, this paper explores the practices of correspondence by postcards and its different uses among the travelling experience, the different modes of seeing, communicating and interacting. The relation between the visual and the textual is, thus, a central issue for the interpretative analysis.

KEYWORDS: postcard, uses, appropriation, travelling experience, touristic seeing.

*Correspondencia a: María Ángela Cifuentes Guerra - maria.angela.cifuentes@gmail.com - https://orcid.org/0000-0002$1572-1850$.

Cómo citar: Cifuentes Guerra, María Ángela (2020). «Postales, viaje y turismo: la experiencia de una viajera ecuatoriana a inicios del siglo XX); Historia Contemporánea, 63, 585-630. (https://doi.org/10.1387/hc.20241).

Recibido: 24 septiembre, 2018; aceptado: 6 marzo, 2019.

ISSN 1130-2402 - elSSN 2340-0277 / (C) 2020 UPV/EHU 


\section{Introducción}

Entre 1911 y 1914, la ecuatoriana Rita de Naranjo firmó una serie de tarjetas postales a familiares y conocidos desde los diferentes lugares de su visita por Europa y los puntos de paso durante su travesía. De esa manera, estableció con ellos una continua correspondencia de envío y recepción de misivas. La tarjeta fechada el 12 de diciembre de 1911 marca el posible inicio de la ruta de su viaje desde la ciudad de Guayaquil con dirección a Lima y luego hacia diferentes sitios entre América Latina y Europa.

¿Cuál fue la razón para su viaje? Apenas puede conocerse mediante los mensajes cortos escritos en las tarjetas postales, pues no consta ninguna declaración explícita. Tampoco existe documentación de respaldo que arroje datos más precisos sobre su edad o profesión. Su visita a diferentes puntos de Europa coincide, sin embargo, con la tendencia de viajeras latinoamericanas de finales del siglo XIX e inicios del XX. Eran mayormente mujeres de élite que viajaban sobre todo con sus parejas para realizar el Grand Tour por Europa a manera de recorridos turísticos de formación. ${ }^{1}$ El caso de Rita podía seguir esta línea. Pero, si bien informó a su hermana en una postal sus dudas de sufrir una enfermedad sin precisar qué padecía, ${ }^{2}$ no se descarta que en su estancia pudo haber combinado turismo con motivos de salud, tanto en su propio caso como en el de Ángel, su marido, según lo comentado en otras notas dirigidas a sus familiares. ${ }^{3}$

Un total de 215 tarjetas fueron cuidadosamente conservadas y ordenadas dentro de un álbum, gracias a lo cual ha sido posible seguir la co-

1 Sanhueza, 2015, p. 337; Vicuña, 2001, p. 103-104.

2 Con fecha 7 de junio de 1913, Rita escribió desde París a su hermana, Adelina, comentándole la situación de padecer una enfermedad, sin especificar mayores detalles al respecto: «Por la carta de Angel te impondras [sic] de mi enfermedad que despues [sic] de esta semana ó mas dias [sic] se sabra el diagnostico [sic], no tengas cuidado yo te comunicare [sic] todo solo pide á la Virjen [sic]». AHMCYP, Quito, Fondo Postales extranjeras, código de la postal: 84.F.19.139.

3 En la tarjeta desde París dirigida a su hermana con fecha 24 de mayo de 1913, Rita le comenta sobre la convalecencia de su marido, Ángel, luego de ser operado; en una siguiente, fechada el 30 de mayo de 1913, le comenta a su madre la salida de su marido de la casa de salud en París, «[...] en donde como ya sabía se opero [sic] Angel y á convalesido [sic] muy bien quien junto conmigo la saludamos con todo cariño». AHMCYP, Quito, Fondo Postales extranjeras, códigos de postales respectivamente: 84.F.19.124, 84.F.19.143. 
rrespondencia dentro de los continuos envíos. ${ }^{4}$ De pasta dura, la portada del álbum guarda en la parte superior el motivo de una joven dentro de un ambiente campestre. Su especialidad de ser un objeto para coleccionar y conservar tarjetas es delatada por la inscripción con letras doradas en la parte inferior que señala «tarjetas postales». Este álbum, conservado cuidadosamente, hace parte de una cultura de colección de finales del siglo XIX e inicios del XX, existente también para tarjetas de visitas (carte-de-visite) o fotografías. ${ }^{5}$ Cada página al interior es de cartón grueso con ventanas caladas y pestañas en las cuatro esquinas para colocar las tarjetas de manera ordenada. ${ }^{6}$ Estos objetos eran guardados como recuerdos de convenciones sociales gracias al intercambio de saludos, deseos o notas específicas. Formaban parte, a la vez, de una cultura intimista romántica centrada en el objeto como detalle entre la persona remitente y la destinataria.

Si bien a través de este material documental resulta complejo conocer en profundidad detalles de la vida de quienes participaron en aquella continua correspondencia, las tarjetas permiten saber quiénes tomaron parte en este intercambio epistolar, desde qué lugares y hacia dónde iban dirigidas. Rita, quien aparece en su gran mayoría como remitente, se dirigía a sus destinatarios residentes en la ciudad ecuatoriana de Ambato desde los diferentes sitios que iba recorriendo a través de una diversa selección de postales. Entre las personas a quienes envió con más frecuencia constan su madre, Mercedes viuda de Ortega, y su hermana, Adelina de Vásconez, ambas domiciliadas en Ambato, por lo que puede deducirse que la viajera provenía de esa ciudad.

Siguiendo la información extraída de las tarjetas, Rita hizo el viaje junto a su marido, Ángel Naranjo, por diversos países de Europa y América Latina, partiendo desde Guayaquil-Ecuador con un paso por la ciudad de Lima, luego Santiago de Chile y Buenos Aires. En esta última pudie-

${ }^{4}$ Este álbum se encuentra en el repositorio fotográfico del Archivo Histórico, perteneciente en el momento de la investigación al Ministerio de Cultura y Patrimonio del Ecuador (AHMCYP), en Quito, dentro del Fondo Postales extranjeras (código 84.F.19). Para este estudio se ha respetado el orden de las tarjetas dentro del álbum hasta la última fecha de su consulta en julio de 2019.

5 Priamo, 1999, p. 277.

${ }^{6}$ Para el caso de álbumes de fotos, Walter Benjamin señala la costumbre de colocarlos en determinados lugares de los hogares europeos, sobre consolas o veladores en los recibidores, «encuadernados en piel con repulsivas incrustaciones metálicas y hojas de un dedo de espesor y con los cantos dorados». Benjamin, 2005b, p. 35. 
ron haberse embarcado a Europa, según se deduce del mensaje desde Santiago a su cuñado, Ernesto, el 19 de enero de 1912.7

De sus múltiples desplazamientos sobresale el placer por ciudades y monumentos, tal como lo declaró Rita a su hermana, el 4 de abril de 1913, cuando hacía su visita en Roma «[c]on el deseo de conocer tanto monumento celebre que esta ciudad tiene y sobre todo las reliquias antiguas $\gg{ }^{8}$ Si bien su viaje coincide con un tiempo cuando el turismo fue diversificándose socialmente en Europa más allá de una pequeña élite aristocrática, ${ }^{9}$ no sucedió de la misma manera en Latinoamérica, pues el viaje de vacaciones al viejo continente habría significado una gran experiencia de vida para un grupo social privilegiado. Pasmiño Yáñez explica la importancia para familias de la alta sociedad chilena de viajar a Francia u otros países europeos con fines vacacionales, pero al mismo tiempo para «instruirse». Algo similar habría ocurrido para familias de otros países de la región, quienes veían a Francia como «el faro iluminador y modelo a imitar, no sólo en nuestro país sino también en el resto de Latinoamérica». ${ }^{10}$ Se insertaban así en una tendencia «aristocrática» del Grand Tour como posibilidad de vivenciar las formas de vida europeas y, más aún, la riqueza cultural occidental que se medía en las artes y la arquitectura. ${ }^{11}$

Junto a ello, la adquisición de tarjetas fue haciéndose cada vez más abierta a diferentes grupos sociales, así también la afición por coleccionarlas. ${ }^{12}$ El caso de estudio corresponde a una pareja viajera sudamericana, procedente de una pequeña ciudad de los Andes de Ecuador; ${ }^{13}$ su capacidad de desplazarse hacia el exterior por diferentes rincones du-

7 Según el mensaje, Rita y Ángel viajaban a Buenos Aires en tren desde Santiago. Habían planeado permanecer un mes en Buenos Aires para luego seguir desde allí el viaje a Europa. AHMCYP, Quito, Fondo Postales extranjeras, código de postal: 84.F.19.95. Pasmiño Yáñez señala la ruta del estrecho de Magallanes, en Chile, como otro punto de embarque a Europa en aquel tiempo para largas travesías en barco. Pasmiño Yáñez, 2016, p. 63-64.

8 AHMCYP, Quito, Fondo Postales extranjeras, código de postal: 84.F.19.117.

9 Según Marc Boyer, hacia 1900 los burgueses europeos siguieron aficiones turísticas de la aristocracia, emergiendo así nuevas clases sociales provenientes de grupos asalariados, entre otros, profesores que contaban con periodos más largos de vacaciones o empleados de ferrocarril (exentos de pagos de sus desplazamientos en tren). Boyer, 2002, p. 27.

10 Pasmiño Yáñez, 2016, p. 64.

11 Sanhueza, 2015, p. 337; Vicuña, 2001, p. 104.

12 Schwarz, 2010, p. 145.

13 Según datos poblacionales, la ciudad de Ambato contaba en 1922 con 13.050 habitantes. Tomado del cuadro de población de Latacunga, Ambato y Riobamba (1740-1950). Ibarra, 1992, p. 239. 
rante un largo tiempo hace pensar que la pareja combinó en su travesía el placer turístico con otras razones que son nombradas de manera marginal en sus misivas, razón para considerar la manera cómo el caso de estudio expresa la experiencia del viaje en lo visual y lo textual mediante el uso de las tarjetas.

¿Cuáles fueron los lugares visitados por Rita?, ¿cuál fue el modo de verlos y apreciarlos a través de sus mensajes? El objetivo principal se orienta a conocer lo que la tarjeta postal, en tanto objeto de viaje y correspondencia, porta y transmite desde la mirada y experiencia de Rita como viajera extranjera en Europa y América Latina en los envíos postales con sus destinatarios, las relaciones comunicacionales, afectivas y visuales que van siendo construidas a través de los usos dentro de un intercambio entre mundos, ${ }^{14}$ y qué formas de agencias surgen durante la correspondencia, entendiendo esto último desde la apreciación de Arjun Appadurai sobre agencia en tanto formas de acción o respuestas dadas en instancias de placer, ocio o consumo. ${ }^{15}$ La tarjeta funciona asimismo como un medio de comunicación interpersonal; cada una de ellas es portadora de un mensaje dentro del largo diálogo epistolar entre la viajera y sus receptores de correspondencia. Desde esta perspectiva, atender a los usos dados a través del desplazamiento, el intercambio, la representación, la posesión como también la conservación, es imprescindible. En su teoría sobre la economía visual de las imágenes-objeto, Deborah Poole define los valores dados a estas por los usos sociales, su contenido representacional que determina su «valor de uso» y, además, su circulación en el ejercicio de intercambio, correspondencia y consumo que define su «valor de cambio». ${ }^{16}$

Una cultura visual epistolar de intercambios, apreciaciones temáticas y convenciones toma importancia en este análisis; con ello, lo que emerge mediante los usos de las postales. Ha sido central hacer el seguimiento de Rita como transmisora de su experiencia de viaje y turismo y de quienes participaron en este intercambio. Para ello, se han establecido las siguientes preguntas de investigación: ¿cómo relacionaba la viajera el objeto de envío con su experiencia?, ¿hay solamente un valor de uso de la tarjeta a través del motivo representado y como medio de correspondencia, o

${ }^{14}$ Hinnerk Onken afirma que, gracias a su amplio alcance, las imágenes en las tarjetas postales lograron una gran circulación de tipo transnacional, transcultural e incluso transclasista. Onken, 2014, p. 48.

15 Appadurai, 2001, pp. 22-23.

16 Poole, 2000, pp. 20-21. 
existe además un valor de recuerdo o afectivo?, ¿qué motivos fueron seleccionados por las personas en este intercambio, y qué valor adquirían estos dentro de la correspondencia?

La tarjeta postal ha sido la fuente primaria de este estudio como documento de viaje, de intercambio y, a la vez, de colección. Ha sido imprescindible relacionar desde la hermenéutica lo textual con lo visual de las imágenes y sus motivos a manera de construcciones simbólicas que, en sí mismas, a decir de José Luis Brea, son «una puerta abierta a la interpretación». ${ }^{17}$ Lo textual, desde los mensajes emitidos por los participantes de este intercambio epistolar, ha sido analizado en conjunto con lo visual a fin de realizar metodológicamente el seguimiento del relato de la viajera y su recorrido, el uso simbólico de las imágenes para la emisión de sus mensajes, así como los motivos elegidos. De ese modo se ha tomado atención sobre la manera de actuar a través del mensaje de la tarjeta en este cruzamiento entre la imagen del motivo y el mensaje expuesto dentro del texto de una persona a otra, de un mundo a otro.

\section{La tarjeta postal entre la comunicación y el turismo}

En sus inicios, la tarjeta postal hacía las veces de medio de comunicación personal para el envío de misivas o para concertar citas. ${ }^{18}$ Fue una costumbre que se extendió por varias ciudades de Europa antes de que sus usos se diversificaran hacia fines publicitarios, profesionales y, más aún, turísticos. ${ }^{19} \mathrm{Si}$ bien la idea de un medio de comunicación abierto produjo inicialmente sus críticas, ${ }^{20}$ el ministro de Comercio austro-húngaro, tras la intervención del barón Adolf Maly, promulgó una orden real para la cir-

17 Brea, 2010,p. 9.

${ }^{18}$ Lois y Troncoso, 2017, p. 634.

19 Según Carla Lois y Claudia Troncoso, el uso cotidiano de la tarjeta para el envío de noticias o concertar citas se dio en ciudades europeas como París, Berlín, Londres, entre otras más. Este tipo de correspondencia frecuente por medio de tarjetas podía darse gracias a las entregas postales, incluso tres veces por día. Lois y Troncoso, 2017, p. 634. En España, su primera aparición data de 1871; en 1873 se la despachó como entero postal. Guereña, 2005, p. 36.

${ }^{20}$ Según Mariana López Hurtado, la crítica se dio en torno a la introducción de hojas postales en forma de talonario, como un medio de comunicación no reservado, dentro de la Conferencia Postal Internacional llevada a cabo en Karlsruhe, Alemania, en 1865. Esta propuesta fue rechazada por la falta de intimidad de la tarjeta al no llevar sobre. López Hurtado, 2013, p. 33. 
culación de la Briefharte (tarjeta postal) en Austria, el 1 de diciembre de 1869. ${ }^{21}$ Gisèle Freund señala la promulgación en Alemania de la ley de circulación de postales en 1865, (posiblemente relacionada a la Conferencia Postal Internacional en Karlsruhe) y, acto seguido, en Francia en 1872. Sin embargo, tuvo gran auge en el mercado recién hacia $1900 .^{22}$

Su uso turístico surgió del interés por mostrar imágenes de lugares a conocer, apreciar y visitar. De las ciudades, fue importante hacer visible su belleza y modernización a través de la técnica, medios de transporte, vialidad, electricidad, monumentos o ejemplos de arquitectura emblemática. La ciudad fue considerada como uno de los motivos para representar la modernidad. El viajero visitante adquiría una tarjeta postal con vistas de determinados rincones, monumentos, edificios, lugares públicos, relacionando de manera inmediata su adquisición con el instante experimentado en su visita. Adquirir la tarjeta impresa con la fotografía del lugar significaba una manera personal de sellar ese recuerdo en el momento y el sitio de su experiencia pasajera para transmitirlo a otros por medio del envío postal, o conservarlo como souvenir. Como tal, se convirtió en un objeto de consumo de viajeros con el cual era posible intercambiar saludos, comunicarse, congelar en el tiempo y en el espacio instantes de una experiencia transitoria. ${ }^{23}$

Una cultura epistolar se fue profundizando mediante la costumbre de enviar saludos y deseos a través de tarjetas ilustradas. Era un equivalente visual que el visitante podía usar para mostrar el lugar, el paisaje o las vistas que había gozado durante su recorrido. A la vez, el intercambio de estas imágenes-objeto significó una manera de «democratizar» el conocimiento de la vida en otros mundos, de la gente, la moda, entre otros aspectos, pues recibir una de ellas con vistas de lugares desconocidos habría sido muy apreciado para quienes viajar resultaba una actividad difícil de practicar. ${ }^{24}$

Desde Europa y Estados Unidos, la tarjeta postal turística se internacionalizó a diferentes partes del mundo. El turismo hizo que su uso se propagara cada vez más. ${ }^{25}$ En América Latina fue utilizada desde finales del siglo XIX y tuvo un rápido crecimiento en las primeras décadas del si-

${ }^{21}$ López Hurtado, 2013, p. 33-34.

22 Según Freund, hacia 1910 ya se habían impreso únicamente en Francia alrededor de 123 millones de tarjetas postales. Freund, 1983, p. 90-91.

${ }_{23}$ Palou Rubio, 2006, p. 21; Santillán, 2010, p. 72.

24 Schwarz, 2010, p. 145.

25 Freund, 1983, p. 91. 
guiente siglo. ${ }^{26}$ Los motivos fueron diversos, tomando a la ciudad entre uno de los temas más recurrentes. Se mostraba la modernidad desde el esplendor de la arquitectura, los pasajes, obras de ingeniería, transporte, puertos, etc. ${ }^{27}$ Las imágenes fueron realizadas por fotógrafos locales o europeos residentes en América Latina, y producidas en el formato de tarjetas postales en Alemania, Gran Bretaña, entre otros países de Europa. Estas eran vendidas más tarde a coleccionistas en cada uno de los países donde fueron realizadas las fotografías. Varios de ellos, provenientes de Europa, las adquirían incluso en diferentes lugares de América Latina para enviarlas de vuelta a amigos o familiares del norte. ${ }^{28}$

Para el caso de Chile, por ejemplo, las primeras postales con motivos del país, mayoritariamente vistas de Valparaíso, Santiago y Valdivia, las imprimió en Alemania Albert Auftt dentro de una colección de diferentes lugares a nivel mundial. ${ }^{29}$ De igual manera, los editores de tarjetas, en buena medida extranjeros de origen europeo,${ }^{30}$ fueron ampliando la producción y el mercado de postales en diferentes países de América Latina. También se publicaron álbumes de ciudades, como el caso en Ecuador de Quito a la vista ${ }^{31}$ realizado por Roberto Cruz y el fotógrafo José Domingo Laso. ${ }^{32} \mathrm{De}$ la misma ciudad tuvieron gran acogida las tarjetas con fotografías de nuevas edificaciones, parques, pasajes o la moda que se copiaba de Europa. ${ }^{33}$

En un inicio, las tarjetas fueron adquiridas por sectores urbanos de clase media y alta, familiarizándose con los motivos impresos, sus diferentes usos y funciones al igual que las posibilidades para coleccionarlas. Más tarde se amplió el público aficionado entre diferentes sectores sociales. Eran vendidas en locales comerciales de las ciudades: las mismas casas editoriales, estudios fotográficos, librerías o estancos. ${ }^{34}$ Sin duda, el coleccionismo se diferencia de otras prácticas por reducirse al placer de

26 Onken, 2014, p. 49.

27 Onken, 2014, p. 54.

28 Onken, 2014, p. 49.

29 Burgos Cuthbert, 2006, p. 16.

30 Onken, 2014, p. 50; Burgos Cuthbert, 2006, p. 15.

31 Para el caso de Guayaquil hubo un criterio de selección de fotografías que conformaron el álbum de la ciudad, siendo los temas centrales la movilidad social, la seguridad social, la limpieza del puerto. Puello Sarabia, 2008, pp. 93-94.

${ }^{32}$ Bedoya, 2011, p. 65.

33 Entre los fotógrafos destacados al respecto constan los nombres de Ignacio Pazmiño, José Domingo Laso, entre otros.

${ }^{34}$ Onken, 2014, p. 51. 
adquirir y conservar las tarjetas con diferentes motivos y formatos. ${ }^{35}$ Para Benjamin, la práctica de coleccionar libera al objeto de todas sus funciones originales al «entrar en la más íntima relación pensable con sus semejantes». ${ }^{36}$ Podemos suponer esta íntima relación con sus semejantes en el repositorio del coleccionista, en aquel «círculo mágico», según sus propias palabras. Está, además, el sentido del recuerdo que se desea guardar y perpetuar, junto al placer voyeurístico por conocer formas de vida de otros lugares que llegaban impresas en los motivos de las tarjetas. ${ }^{37}$

Este placer acentuó la práctica de coleccionar, el interés por conservar recuerdos de viajes al igual que detalles de experiencias de otros que han llegado hasta nosotros en forma de saludos o misivas a través de las postales. Burgos Cuthbert considera que el coleccionismo de postales en álbumes se presentó como una actividad apreciada hasta aproximadamente los años veinte del siglo Xx, luego de lo cual fue apaciguándose. ${ }^{38}$ Esa época coincide con los años de correspondencia de Rita de Naranjo con sus familiares y conocidos. Varias de las tarjetas conservadas en el mismo álbum, con ilustraciones de lugares en Europa, en blanco y negro o coloreadas, no contienen mensaje escrito en su reverso ni tampoco sello postal; a estas se añaden varias otras con motivos de la construcción del canal de Panamá, sin fecha de adquisición ni misiva alguna. ${ }^{39}$ Todas estas pudieron haber sido objetos de colección, sea de Rita o de su marido, o bien por encargo de algún familiar justamente con ese propósito.

Los motivos varían entre vistas urbanas, monumentos, edificaciones emblemáticas o museos, al igual que tarjetas ilustradas, no necesariamente fotográficas, que llevaban motivos conmemorativos para expresar deseos o felicitaciones específicas. Lo curioso del caso en estudio es que, dentro de la correspondencia entre Rita y sus allegados, las postales guardan dentro del álbum un cierto seguimiento de los desplazamientos de Rita, si bien no existe un orden cronológico sistemático por lo que varias de ellas rompen con una linealidad. En su conjunto, esta colección consti-

35 Durante las épocas victoriana y eduardiana, las familias de clase media adquirían los álbumes de tarjetas con fines de entretenimiento, marca de identidad e incluso de estatus social. Pritchard y Morgan, citados por Lois y Troncoso, 2017, p. 638.

36 Benjamin, 2005a, p. 223.

37 Ado Kyrou citado por Freund, 1983, p. 91.

38 Burgos Cuthbert, 2006, pp. 18-19.

39 Se trata de un grupo de tarjetas postales con diferentes vistas de la construcción del canal, con inscripciones en inglés. AHMCYP, Quito, Fondo postales extranjeras, códigos de las postales: 84.F.19.196-206. 
tuye una suerte de relato visual y textual de un periodo epistolar. Demuestra, en sí, el significado histórico y afectivo que pudieron haber adquirido las tarjetas como documentos familiares cuidadosamente guardados en el álbum, valorados más tarde con fines archivísticos y científicos desde el interés del investigador o investigadora, en tanto la postal constituye una rica fuente documental histórica e iconográfica.

\section{La experiencia de viaje: visualidad, movilidad y turismo}

Gracias a la experiencia de viaje, la tarjeta postal reúne la visualidad, la movilidad y el turismo. Como medio visual, la tarjeta encierra un aspecto esencial de la experiencia turística al representar el lugar o el instante vivido que el/la turista quiere conservar en el objeto para el recuerdo. Este deseo determina la selección del motivo y el destino hacia donde irá dirigido, o si será conservado como un objeto de colección.

Lois y Troncoso relacionan turismo y visualidad dentro de la tarjeta postal mediante el concepto de mirada turística, de John Urry. ${ }^{40}$ Según este concepto, el acto de ver implica dimensiones sociales, culturales e históricas que determinan el interés del turismo por ciertos lugares y objetos. Dicho así, la mirada turística accede a una información generada previamente para ser experimentada y consumida visualmente.$^{41}$ Esta mirada está hecha con ojos del/la visitante extranjero/a ${ }^{42}$ quien, a la vez, busca satisfacer deseos o expectativas que había tenido previamente de sitios, monumentos, culturas. Las imágenes seleccionadas reproducen representaciones previamente elaboradas respecto a esos mismos puntos o culturas en un tipo de agenciamiento proveniente de imaginarios de turismo previamente existentes. Estos imaginarios, según Rodolfo Bertoncello, conducen a los turistas a manera de «guías» a actuar de determinada forma sobre los lugares y los hechos ${ }^{43}$ La postal servía para la reproducción de estos imaginarios, pues, quien los recibía desde lejos, proyectaba aquellos sitios distantes y desconocidos a través de narraciones visuales y textuales sobre ellos.

40 Para Urry, la mirada turística «es construida a partir de signos y [...] los turistas (como practicantes de semiótica) buscan en el paisaje signos preestablecidos, aquellos que derivan de discursos sobre viajes y turismo». Lois y Troncoso, 2017, p. 635.

${ }^{41}$ Lois y Troncoso, 2017, p. 635.

42 Palou Rubio, 2006, p. 14.

43 Bertoncello, 2012, p. 213. 
Hay que considerar, sin embargo, que el viaje por placer de inicios del siglo XX tenía un significado diferente al que existe hoy en día cuando el turismo se ha masificado al igual que se han diversificado de manera extrema las formas de registrar visualmente los lugares visitados. ${ }^{44}$ En aquellos años, la tarjeta postal servía de objeto visual de lugares vistos y gozados, de recuerdo de alguna vivencia específica, pero también de objeto cultural para el intercambio, la comunicación, la colección. Era, y ha sido por mucho tiempo, un instrumento de sociabilidad entre familiares, conocidos y amigos. ${ }^{45}$ Lo que ha unido al uso de la tarjeta postal y la fotografía del turista ha sido el deseo de constatar la experiencia del viaje, su goce de lugar en lugar. ${ }^{46}$

La tarjeta postal cumplía este rol como portadora de una imagen establecida, así como medio hacia interpretaciones subjetivas sobre otros mundos. El/la turista agenciaba en la producción de imágenes con su apreciación y selección de motivos. No era «únicamente» un agente pasivo ante la producción y circulación de imágenes, pues su gusto y predilección por determinados motivos, tomas o tipos de representaciones implicaban acciones directas y, por ende, claves dentro del mercado de tarjetas. Dicho así, la adquisición de determinadas postales estuvo definida también por cuestiones de gusto, afecto o recuerdos, elegidas con el deseo de transmitir a otros su propia experiencia sobre un lugar, un paisaje o un monumento, o para expresar sentimientos en un tiempo y espacio determinados, siendo el motivo un vínculo simbólico dentro del intercambio interpersonal.

Para el caso de estudio, la selección de motivos representados estuvo estrechamente relacionada a la intención para el envío y a quién iba dirigido. Para Rita fue importante relatar los puntos de su recorrido a través de las imágenes a manera de «ventanas» de los lugares de visita; mientras, las tarjetas de sus familiares y amistades encerraban motivos conmemorativos de felicitación o para emitir saludos específicos. De los envíos efectuados por la viajera, su gran mayoría correspondieron a tarjetas con temas urbanos entre paisajes o vistas panorámicas, escenas callejeras, iglesias, monumentos o palacios, e incluso temas celebratorios en honor a

${ }^{44}$ Marc Augé critica, precisamente, cómo el turismo ha cambiado su valor de práctica social y cultural debido a su masificación; de esta manera ha perdido el encanto del sentido de viaje como descubrimiento y conocimiento, transmisible en el modo de ver. Augé, 2008, pp. 15-16.

45 Guereña, 2005, p. 36.

46 Sontag, 1989, p. 19. 
algún monarca. Pocas tarjetas comprenden motivos conmemorativos para felicitación o fechas específicas de celebración. Los lugares desde donde envió sus tarjetas fueron: Guayaquil, Lima, Santiago de Chile, Buenos Aires, Barcelona, Bordeaux, París, Londres, Bruselas, Amberes, Colonia, Berlín, Viena, Milán, Venecia, Florencia, Niza, Turín, Pisa, Roma, Vittel, Luxemburgo, Montecarlo, Lourdes, Bougival, entre otros.

Varias de las tarjetas despachadas, sobre todo aquellas fechadas durante su posible último año de correspondencia en 1914, tuvieron lugar desde París. Esta pudo haber sido la ciudad donde Rita y su marido permanecieron por más tiempo, incluso a donde fueron enviadas varias de las postales de sus familiares y amigos. ${ }^{47}$ De cada punto visitado, Rita seleccionaba lugares emblemáticos, varios de los cuales tenían relación con paisajes o, más aún, con rutas culturales en torno a monumentos artísticos y arquitectónicos. Su viaje sigue, en gran medida, las expectativas de «cultivarse» en el Grand Tour por Europa, familiarizándose personalmente con obras de arte, arquitectónicas y lugares de culto. En su caso, los sitios religiosos tuvieron una dedicación especial, por ejemplo, Lourdes. Varias de las postales provenientes de esta ciudad de peregrinación fueron guardadas sin sello ni mensaje, lo que supone su interés por conservarlas como recuerdos de colección de su visita.

El motivo de la primera tarjeta del viaje de Rita, enviada desde Guayaquil-Ecuador, donde el 12 de diciembre de 1911 se embarcó hacia Lima, encierra la vista al río Guayas con tres niños bañistas en primer plano (figura 1). Dentro de la composición de la imagen, el río y la barca guardan relación con su vivencia en el momento de emprender la travesía. Poco antes de su partida, escribió en el reverso de la tarjeta un mensaje a su hermana pidiéndole noticias y respuesta a su telegrama. Este pedido fue repetido varias veces durante los siguientes envíos, conservando la tarjeta una función de medio de correspondencia vivo para mantener contacto con su familia y dar cuenta de las próximas visitas dentro de sus rutas de viaje. A su llegada a Barcelona, Rita utilizó para su mensaje dirigido a su madre, el 1 de marzo de 1912, una tarjeta con la vista panorámica de la ciudad hacia la montaña del Tibidabo. Le informó del largo

47 El 18 de marzo de 1912, Ángel escribió una tarjeta desde París a Ernesto Vásconez, marido de Adelina, pidiéndole que considerara la dirección para el envío de correspondencia debido a que no habían recibido hasta entonces noticia alguna. La dirección anotada fue: «Consulado Gral. Del Ecuador. Av. Wagram, No. 91, París.» AHMCYP, Quito, Fondo postales extranjeras, código de la postal: 84.F.19.14. 
trayecto de dieciocho días de navegación y desde donde emprenderían los próximos destinos a Francia y, posteriormente, a Inglaterra:

Mamita mia querida.

Tres días que nos tiene ya en este lugar despues [sic] de 18 dias [sic] de navegacion [sic] muy feliz pronto saldremos para Francia y de allí iremos a Inglaterra que aquí hay que hacer algo, pida mucho a la Virjen [sic] siga en mi viaje con la suerte de hasta aquí.

Reciba recuerdos de Angel y el afecto y cariño de su hija que le abraza.

Rita de Naranjo. ${ }^{48}$

El entusiasmo provino de la remitente hacia otra forma de interrelación entre imagen y texto, orientada a despertar la curiosidad del destinatario o, imaginariamente, hacerle cómplice del momento de la visita a través de un uso simbólico de la imagen. Su predilección seguía, en buena medida, las grandes atracciones turísticas de inicios del siglo XX enmarcadas en castillos, iglesias, museos ${ }^{49}$ mostrando su atención sobre todo por monumentos religiosos. Hizo así de la tarjeta el umbral para la experiencia compartida desde donde podía narrar su recorrido y sus vivencias. Además, como viajera de Sudamérica, su atención se orientó a formas que denotasen la modernidad y el contraste con la monumentalidad de la Europa clásica en el nuevo siglo que ella apreciaba y destacaba en sus mensajes. Su visita a la catedral de Milán sirve de ejemplo al usar la representación del grabado impreso en la tarjeta dirigida a su madre para narrar su propia vivencia, a manera de presencia imaginaria (figura 2); tomó, así, la figura de los tres caminantes expuestos en el primer plano de la imagen como su propia acción para describir brevemente, con estas palabras, la fachada de la catedral:

Mamita querida.

En esta fecha estuvo su hija paseando en la parte que están esos tres individuos, el gravado [sic] representa la cubierta toda de marmol [sic] del centro de la Catedral de Milan [sic] es bellísima por dentro y fuera toda de marmol [sic] solo la Virjen [sic] que esta [sic] en la cúspide.

48 Tarjeta postal con la vista al Tibidabo en Barcelona, fechada el 1 de marzo de 1912, de Rita de Naranjo a Mercedes v. de Ortega. AHMCYP, Quito, Fondo postales extranjeras, código de la postal: 84.F.19.9.

49 Boyer, 2002, p. 29. 

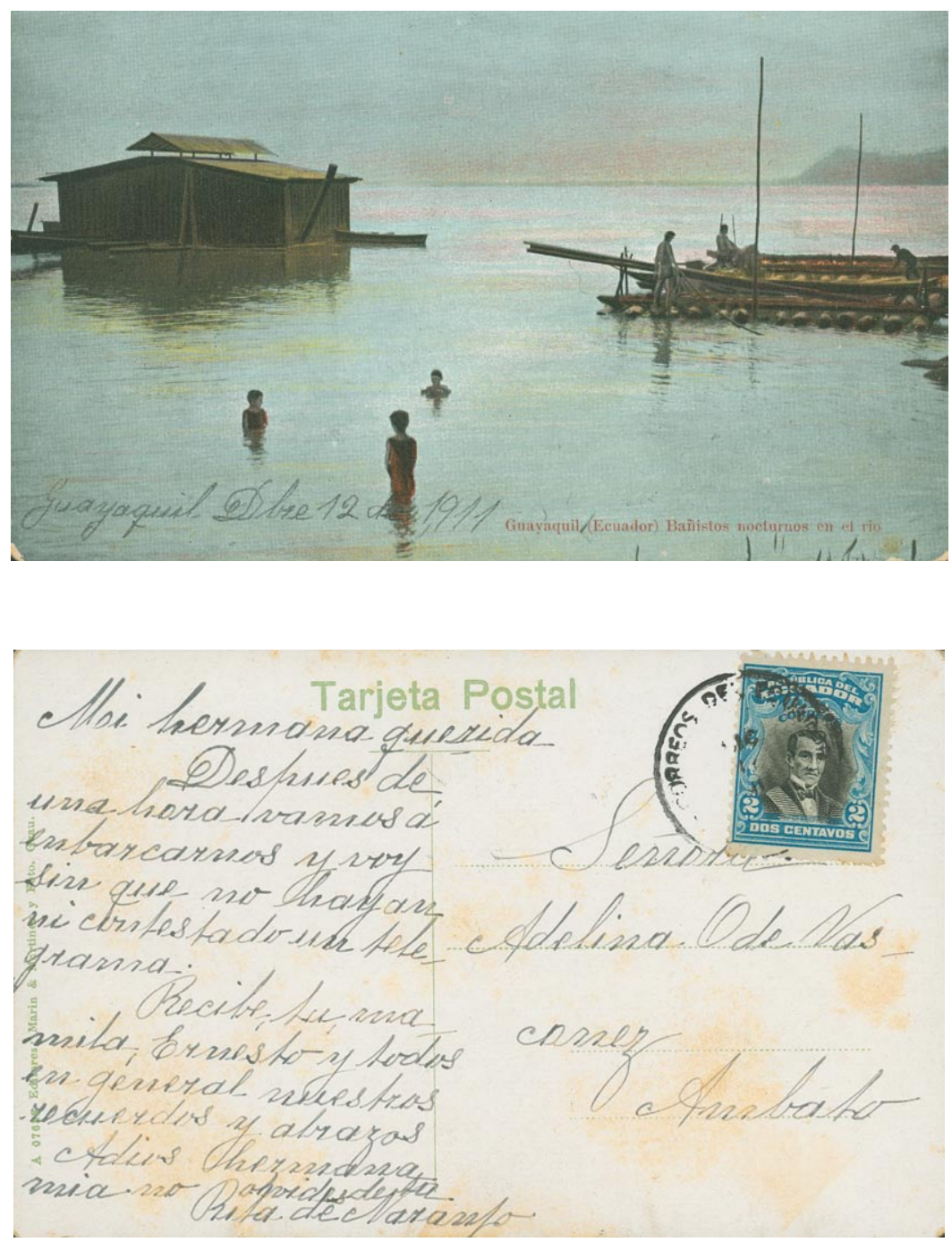

\section{Figura 1}

Anverso y reverso de la tarjeta postal enviada desde Guayaquil por Rita de Naranjo a su hermana, Adelina de Vásconez, el 12 de diciembre de 1911.

Fuente: AHMCYP, Fondo Postales extranjeras, código de la tarjeta: 84. F. 19.1. 

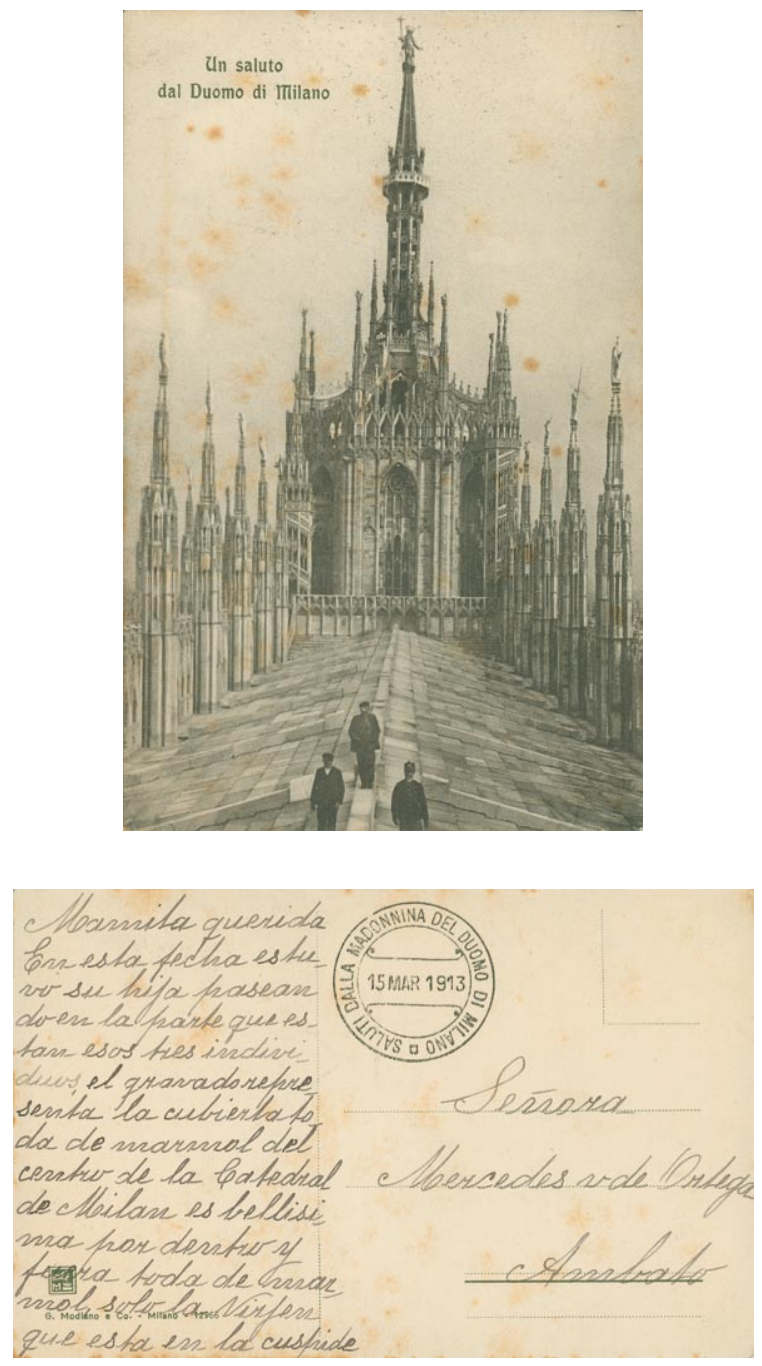

Figura 2

Anverso y reverso de la tarjeta postal con la imagen de la catedral de Milán, enviada por Rita de Naranjo a su madre, Mercedes v. de Ortega, el 15 de marzo de 1913. En la parte superior del lado anverso aparece escrito: «Un saluto dal Duomo di Milano».

Fuente: AHMCYP, Quito, Fondo Postales extranjeras, código de la tarjeta: 84.F.19.58. 
Si bien los mensajes son cortos y puntuales, su uso estuvo orientado muchas veces a relatar brevemente anécdotas relacionadas con el motivo de la postal; este servía como punto de referencia del lugar de la vivencia, pero también del sentimiento que podía emerger de ese contacto. Un caso curioso constituye la relación que Rita estableció entre una vista en torno a la estación de trenes de la celleSaint-Cloud en Gare de Bougival, a las afueras de París (figura 3), y el paisaje de poblados y parroquias que rodeaban su ciudad, Ambato. Encuentra similitud entre los dos lugares a pesar de la distancia geográfica y la diferencia cultural que los separaba. Sin embargo, movida por la nostalgia de su hogar, Rita compara los dos lugares y transmite esta impresión a sus familiares. La tarjeta postal servía de medio visual y textual para describir la experiencia con el lugar; dicho así, el envío involucraba también formas de interrelación geográfica y sentimental por medio de lo visual. En sus palabras, «Bougival es un bosque lleno de quintas en el que mucho é [sic] recordado de nuestros Miraflores, Ficoas y Atocha y llena de tristeza é [sic] pasado con estos recuerdos y el vacio [sic] de Udes». ${ }^{50}$

La selección de la imagen o motivo es un indicador del modo de ver los sitios visitados por la viajera, cuáles merecían su atención y los aspectos que quería comunicar. El lugar físico como punto de referencia de sus desplazamientos sobresalió dentro de su correspondencia. Sin embargo, hubo otros motivos que resultan interesantes de ser considerados, como el caso de su experiencia en la visita de los reyes británicos a París. La tarjeta postal fue un objeto útil no solamente para transmitir el entusiasmo de haber presenciado la llegada de los monarcas, sino también como medio visual para documentar este hecho mediante los retratos de cada uno de ellos. En la postal enviada a sus familiares, el retrato de los reyes se encuentra enmarcado en un medallón con la leyenda inferior de «souvenir of the coronation of their Majesties King George V and Mary Queen of England» (recuerdo de la coronación de sus majestades, el Rey Jorge V y la Reina María de Inglaterra) (figura 4). La relación de esta imagen con el mensaje firmado por Rita desde París dirigido a su hermana, el 24 de abril de 1914, corresponde a su emoción narrada de haberles visto a los monarcas en persona:

${ }^{50}$ Fragmento del mensaje escrito en el reverso de la tarjeta. AHMCYP, Quito, Fondo Postales extranjeras, código de la postal: 84.F.19.138. 
Tan simpáticos como están en esta, han sido los Reyes de Inglaterra, a quienes les é [sic] visto por tres veses [sic] muy de cerca. París mas bonita de lo que es con la [condimentación] y profución [sic] de luces, han estado muy cortejados el recibimiento fue algo de extraordinario, así como é [sic] gozado. Les he pensado a Udes. La hermana que les abraza. Rita de Naranjo. ${ }^{51}$

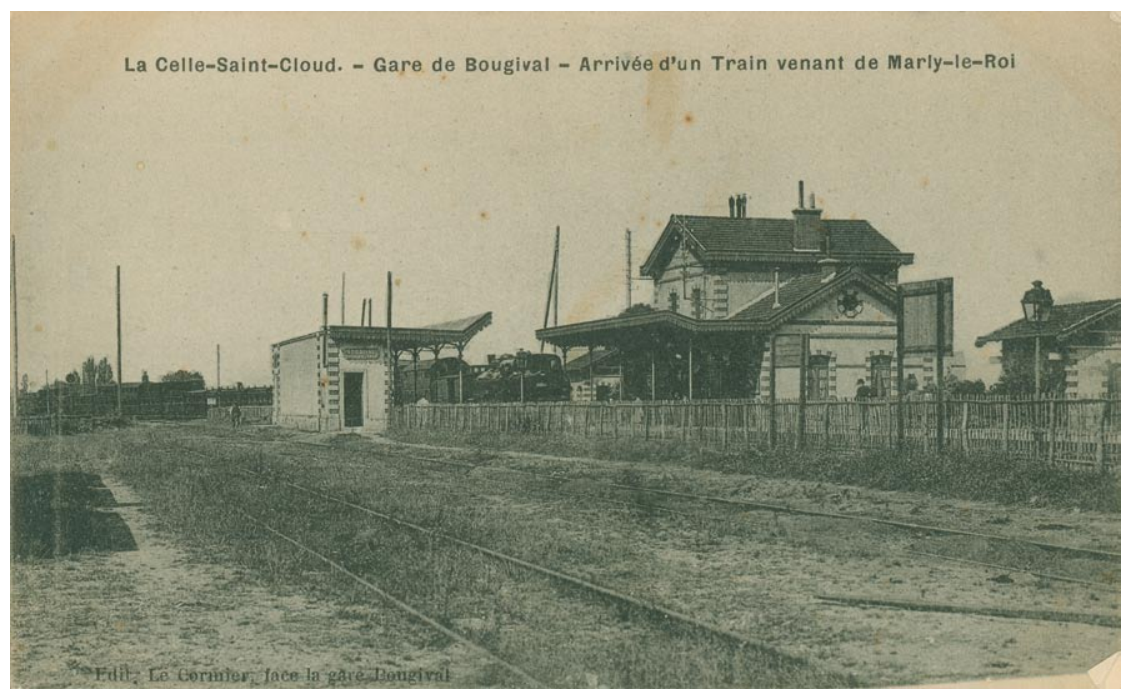

Figura 3

Anverso de la tarjeta postal con el motivo de la estación de tren en la Celle-Saint-Cloud, Gare de Bougival (Francia). Enviada por Rita de Naranjo a su hermana, Adelina de Vásconez, 21 de septiembre de 1913.

Fuente: AHMCYP, Quito, Fondo Postales extranjeras, código de la postal: 84.F.19.138.

51 Fragmento del texto en el reverso de la tarjeta postal dirigida a Adelina de Vásconez. AHMCYP, Quito, Fondo Postales extranjeras, código de la postal: 84.F.19.157. 


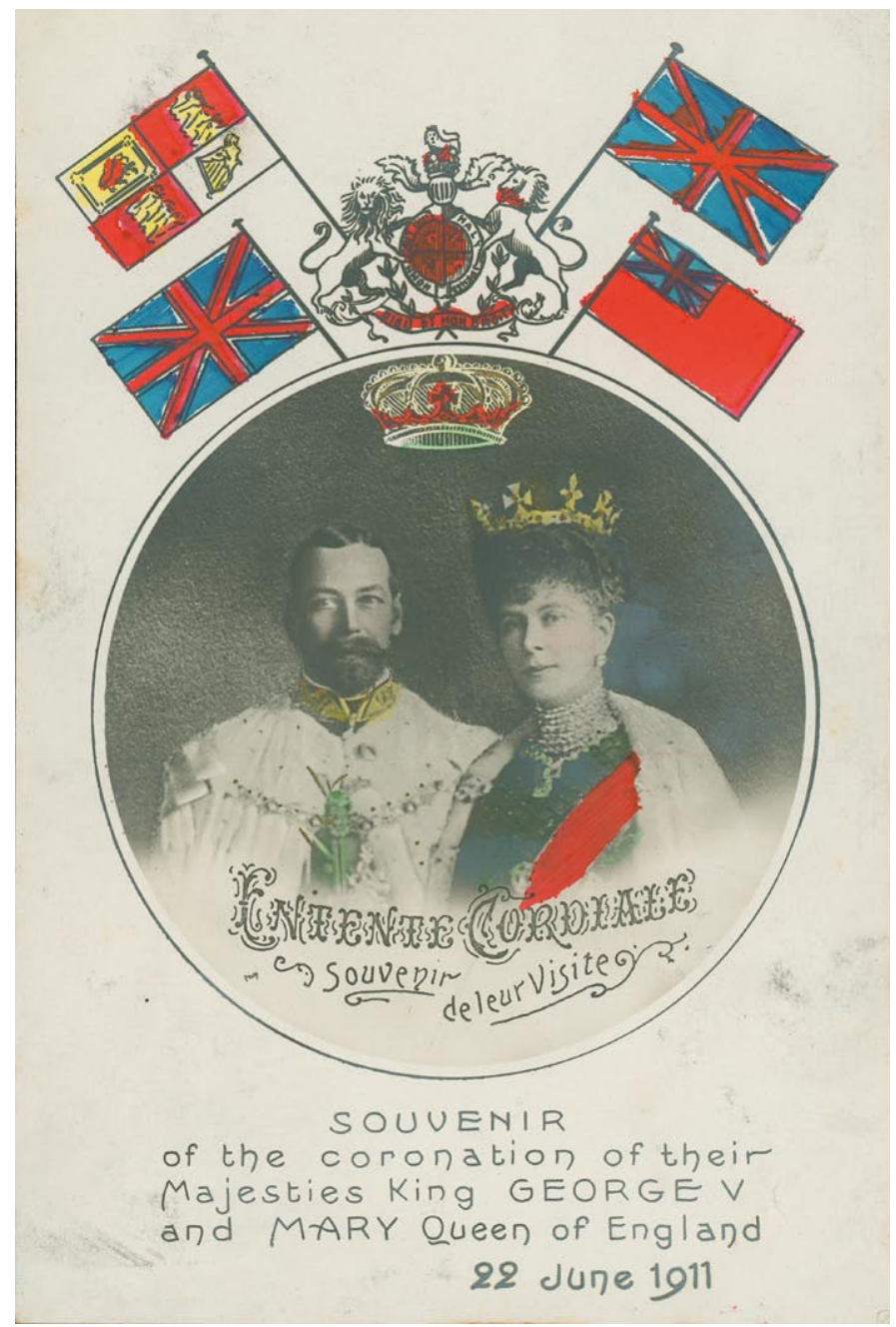

\section{Figura 4}

Lado anverso de tarjeta postal con la fotografía de los Reyes de Inglaterra, Jorge V y María. En el lado reverso consta haber sido hecha la impresión en Francia.

Fuente: AHMCYP, Quito, Fondo Postales extranjeras, código de postal 84.F.19.157. 
Si Rita enviaba sus tarjetas postales con relativa frecuencia desde los diferentes lugares que visitaba, ¿qué tipo de correspondencia recibía ella de sus destinatarios? La diferencia de estar en constante desplazamiento al hecho de hallarse de manera sedentaria en un solo lugar determinó el continuo envío de las tarjetas y la selección de sus motivos. Para Rita fue importante participar los sitios de sus andaduras y experiencias, mantener el hilo comunicativo a través de los constantes desplazamientos; mientras, para sus familiares y conocidos, la tarjeta se presentaba como la portadora de saludos y felicitaciones. Dicho así, a diferencia de las continuas novedades de lugares y monumentos de Europa recorridos y compartidos por Rita mediante la postal, para sus destinatarios era importante dar respuesta a los envíos y tomar atención a fechas clave para saludos conmemorativos. El motivo era una representación simbólica de un estado de ánimo, una atención o una convención en fechas de cumpleaños, Navidad o Año Nuevo, entre otras. Ello se reflejó en el tipo de tarjetas seleccionadas por cada uno de los participantes en este intercambio epistolar. ${ }^{52}$ Fue común enviar postales conmemorativas con motivos ambientados o figuras cercanas al gusto art nouveau, utilizadas muchas veces a manera de mensajeras de deseos de felicitación, convirtiendo a la tarjeta en una especie de visita simbólica.

Al igual que sus familiares y conocidos, Rita tomó parte de este tipo de comunicación con figuras alegóricas para transmitir deseos. Anita, the living doll, es el personaje de una tarjeta conmemorativa enviada desde Londres el 16 de junio de 1912, representada por una niña envuelta en un traje de dama de inicios de siglo en un retrato de estudio coloreado (figura 5). Caracterizándola como «pigmea», Rita hizo de este personaje el portador de su mensaje y abrazos para su hermana:

Querida hermana:

La pigmea de esta va anticiparte que recibo hoy tu última de 8 de mayo y que contestare [sic] en el siguiente correo, mientras tanto te dara [sic] mis abrazos, aunque solo podra [sic] abrazarle las rodillas y dira [sic] que anoche estuvo a conocerla tu hermana, Rita.

52 Una de las excepciones como remitente fue una amiga de Mercedes v. de Ortega, de nombre Elisa. Su envío corresponde a una tarjeta con una fotografía coloreada del monumento a José de Sucre, en la ciudad de Guayaquil. En su mensaje de diciembre de 1912, Elisa escribió: «Hoy le mando el parque Sucre de Guayaquil para que se acuerde de mí. Su amiga, Elisa.» AHMCYP, Quito, Fondo tarjetas postales, código de la postal: 84.F.19.6. 

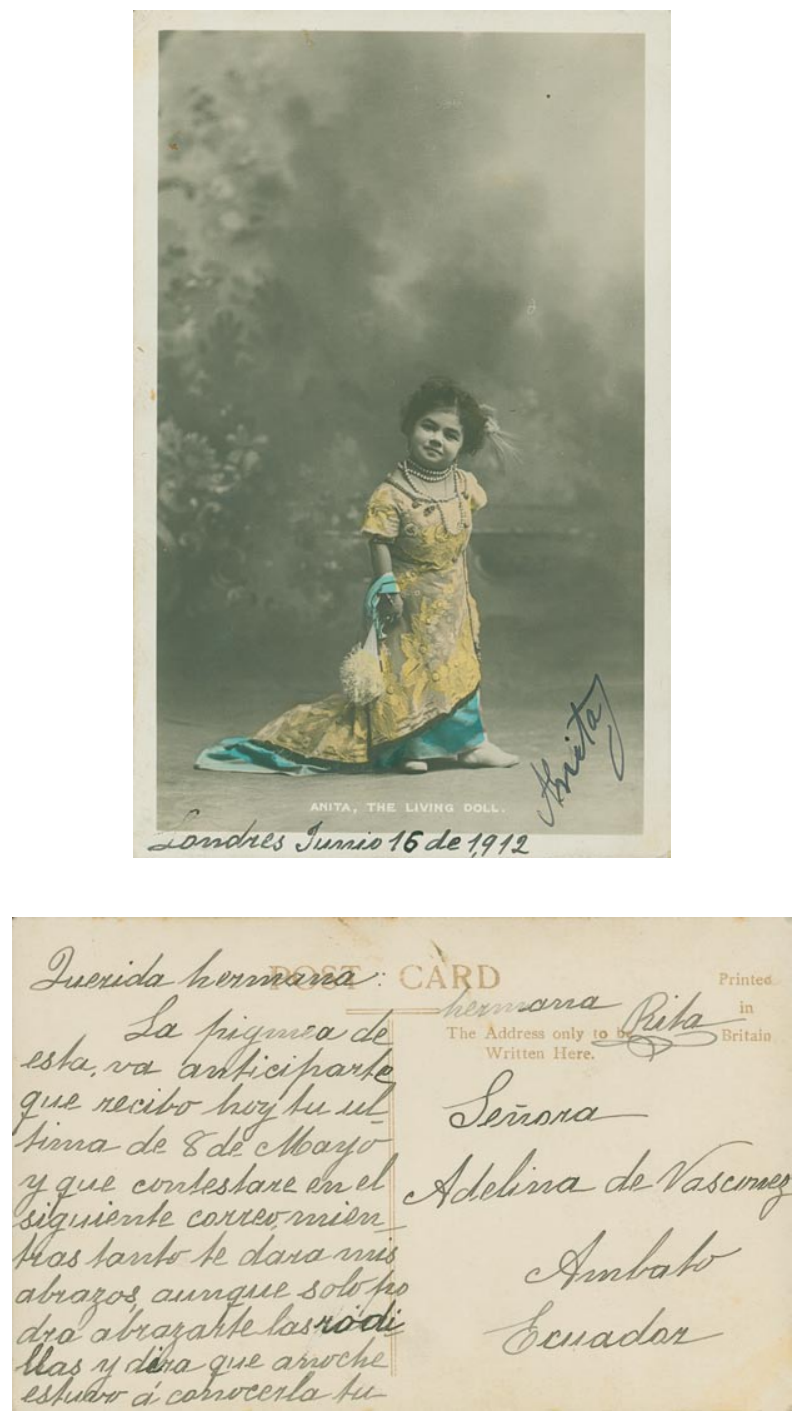

Figura 5

Anverso y reverso de la postal Anita, the living doll. Enviada desde Londres por Rita de Naranjo a Adelina de Vásconez, el 16 de junio de 1912.

Fuente: AHMCYP, Quito, fondo Postales extranjeras, código de la tarjeta: 84.F.19.19. 
Su hermana, Adelina, optó también por tarjetas conmemorativas con motivos idílicos en primer plano, como figuras de niños o mujeres que se convertían en mensajeras imaginarias de sus misivas. La niña flanqueada por un gran corazón rojo en el fondo de la imagen es un ejemplo de una imagen usada por ella el 22 de abril de 1913 (fig. 6). La pequeña fue presentada como «conductora» de sus recuerdos y felicitaciones de cumpleaños enviados a Rita. El hecho de expresar saludos de una determinada manera tenía relación directa con el motivo de la imagen, algo que era transmitido en el mensaje: «va a precentarte [sic] ese corazón que es el mío y manifestarte que mis deseos y mi cariño para ti es tan grande como ese corazón que desea tú [sic] felicidad y mil años de vida»..$^{33}$ Este entrelazamiento visual y textual realizado por la remitente muestra el uso de lo representacional, dándole a la vez un valor simbólico. Se trataba de una apropiación de las formas por parte del remitente para hacer de la postal la portadora de deseos desde la correlación entre palabra e imagen.

Rita debió mantener esta práctica de enviar tarjetas conmemorativas con su entorno familiar y social antes y después de su partida a Europa, pues dentro del álbum consta un envío del 21 de mayo de 1911 por una conocida suya en Ambato con firma Victoria T., quien le expresó brevemente su enhorabuena por el día de su cumpleaños. El motivo de la tarjeta coloreada corresponde al rostro de un niño de rizos rubios, semejante a un ángel, con su cabeza apoyada en un cojín..$^{54} \mathrm{~A}$ diferencia de esta imagen, la que correspondía a una postal de cumpleaños dirigida a Ángel Naranjo, marido de Rita, muestra el retrato de estudio en blanco y negro con la figura cuerpo entero de un niño de rizos rubios, pantalones cortos y botines blancos, cargando en cada una de sus manos una planta en maceta. La tarjeta, con impresión en francés, fue enviada por Reinaldo Salas en Ambato, el 2 de agosto de 1910. En el texto del mensaje, Salas hizo al niño representado el portador de sus saludos: « $\operatorname{Sor}^{55}$ Naranjo: Por no poder hacerlo personalmente, me valgo de este niño, el que es portador de las mil felicidades que le deseo en el día de su natalicio». ${ }^{56}$

${ }^{53}$ Fragmento del texto en el reverso de la tarjeta postal con motivo conmemorativo enviado por Adelina de Vásconez a su hermana, Rita de Naranjo, el 22 de abril de 1913. AHMCYP, Quito, Fondo Postales extranjeras, código de la postal: 84.F.19.7.

${ }^{54}$ En el reverso de la tarjeta, la remitente escribió un mensaje corto con las siguientes palabras: «Señorita Rita: Salúdala y felicítala en este hermoso día de su cumpleaños la que en mayor grado le aprecia. Victoria T.» AHMCYP, Quito, Fondo postales extranjeras, 21 de mayo de 1911, código de la postal: 84.F.19.93.

55 Abreviación de la palabra «señor» que fue utilizada literalmente en el texto original.

56 Texto escrito en Ambato por Reinaldo Salas L. a Ángel Naranjo. AHMCYP, Quito, Fondo postales extranjeras, 2 de agosto de 1910, código de la postal: 84.F.19.94. 

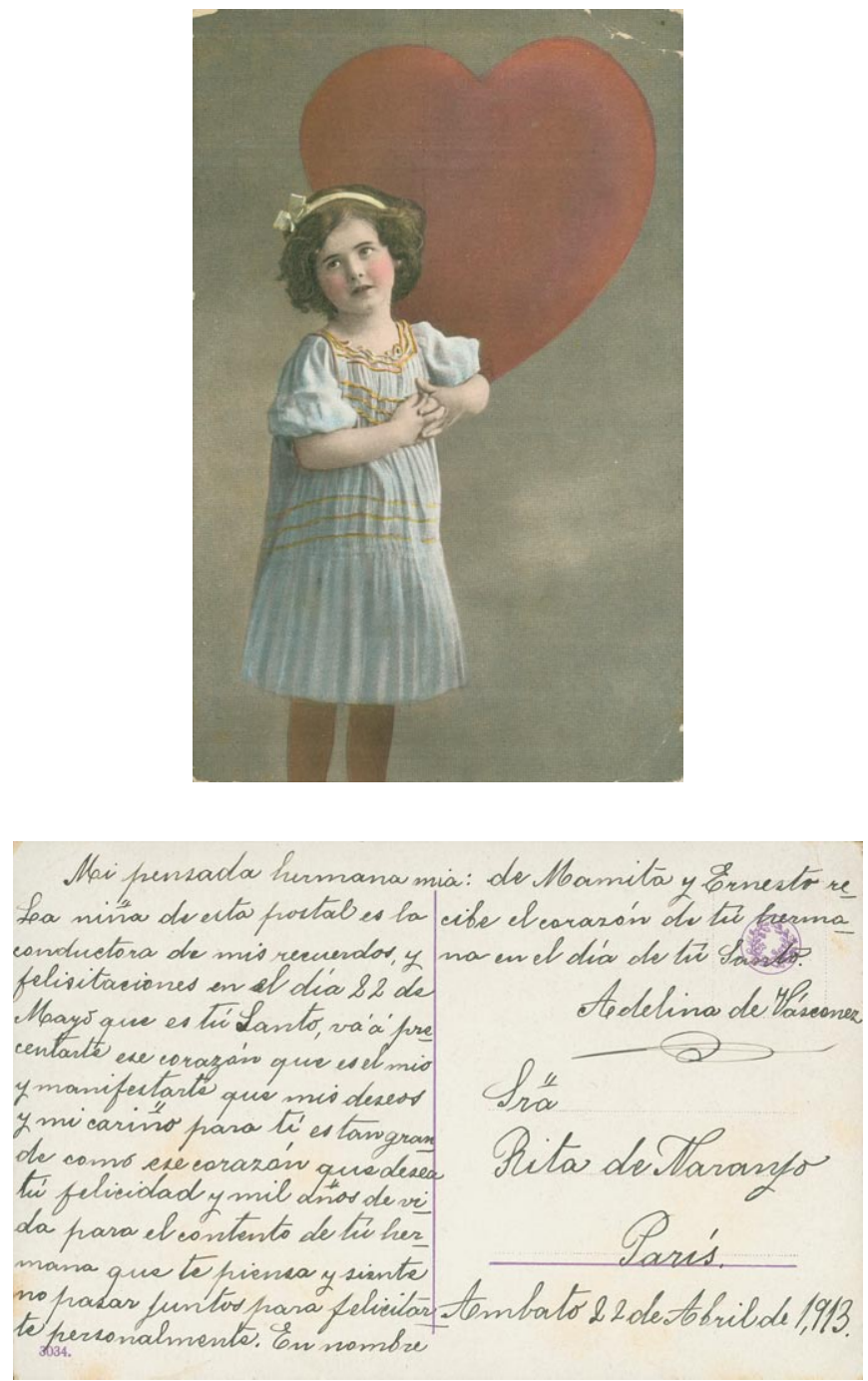

\section{Figura 6}

Anverso y reverso de tarjeta postal conmemorativa enviada por Adelina de Vásconez a su hermana, Rita de Naranjo, 22 de abril de 1913.

Fuente: AHMCYP, Quito, Fondo Postales extranjeras, código de la postal: 84.F.19.7. 
Por los diferentes casos de mensajes en esta línea, es pensable que en aquellos años era común no solamente enviar saludos por medio de tarjetas postales sino, además, hacer al objeto representado el portavoz imaginario de un deseo o felicitación. ${ }^{57}$ Rita continuó con esa costumbre a lo largo de su viaje por Europa, adaptando los motivos de las tarjetas a esta forma de comunicación epistolar.

\section{La postal: objeto entre geografías, personas, culturas}

El viaje trae consigo prácticas de cruces e interacción..$^{58}$ Estas originan un intercambio interpersonal al igual que intercultural. Junto a su utilidad como medio epistolar para la comunicación entre personas, la tarjeta postal implicó un elemento importante dentro de un entrecruzamiento cultural.

Como imágenes-objeto, las postales podían convertirse implícitamente en medios de apropiación o de entrecruzamiento cultural. Resulta inquietante, por ejemplo, apreciar las formas de expresión del correo de Rita de Naranjo durante los años de su comunicación epistolar que mostraban una asimilación de frases, maneras de dirigirse al otro o mensajes que paulatinamente fueron escritos en otra lengua. Constan, por ejemplo, las inscripciones de frases en la misma tarjeta que identifican el tipo de saludo o mensaje a ser emitido como Bonne année (Feliz Año Nuevo), que Rita utilizó para saludar a su familia al inicio de $1914 .{ }^{59}$ Estas postales debieron venderse en temporadas próximas a las fiestas para ser enviadas a diferentes destinos. Está también la tarjeta dirigida a su cuñado, José Ernesto Vásconez, desde París el 3 de julio de 1914, con la inscripción en alemán que re-

57 Años más tarde del periodo de viaje por Europa, Rita recibió una tarjeta fechada el 1 de enero de 1926 con los saludos del Nuevo Año por parte de Mercedes (sin apellido). La imagen corresponde al dibujo de una mujer asiática, portando un kimono y sosteniendo en sus manos una jarra de té. Posiblemente la representación corresponde a una figura japonesa. AHMCYP, Quito, Fondo postales extranjeras, código de la postal: 84.F.19.8.

58 Clifford, 1999, pp. 13.

59 El motivo de la tarjeta coloreada es de felicitación por el Año Nuevo con el retrato de un niño con flores en sus manos. AHMCYP, Quito, Fondo postales extranjeras, código de la postal: 84.F.19.121. 
zaba: Sei wieder gut (ponte bien nuevamente) ${ }^{60}$ El mensaje, escrito por Rita completamente en francés, expresa sus agradecimientos por los buenos pensamientos que le eran transmitidos durante su recuperación. Algo similar lo hizo un día antes, dirigida a su hermana y usando para ello una postal con retrato coloreado de una mujer con estola de piel cuya inscripción en la parte superior señalaba en francés: Heureuse Année (venturoso año). Posiblemente, Rita utilizó la figura de la dama de la ilustración de esta postal conmemorativa para felicitar a su hermana con un mensaje escrito completamente en francés (figura 7).

Escribir sus textos en lengua extranjera puede interpretárselo como un signo de adaptación a la otra cultura, de aprendizaje y, consecuentemente, de un proceso de formación y apropiación de formas culturales que iba más allá de lo sensorial para proyectarse también en lo lingüístico, desde expresiones simples hasta el uso mismo de la lengua en sus misivas. Este proceso personal de adaptación y formación en Rita implicaría, además, el aprendizaje o perfeccionamiento de otra lengua. Ya un año antes, en 1913, había usado la palabra madama en varios encabezamientos, siendo en esta, por ejemplo, la destinataria en Ecuador su hermana, Adelina. ${ }^{61}$

${ }^{60}$ Postal coloreada con la imagen de dos niños en una ambientación campestre, con fondo ambientado a manera de paisaje de campo. AHMCYP, Quito, Fondo postales extranjeras, código de la postal: 84.F.19.145.

61 Correspondiente a la tarjeta postal enviada por Rita de Naranjo a su hermana, Adelina de Vásconez, desde Bougival, el 21 de septiembre de 1913. AHMCYP, Quito, Fondo postales extranjeras, código de la postal: 84.F.19.138. Al respecto, véase la figura 3 dentro de este artículo. 

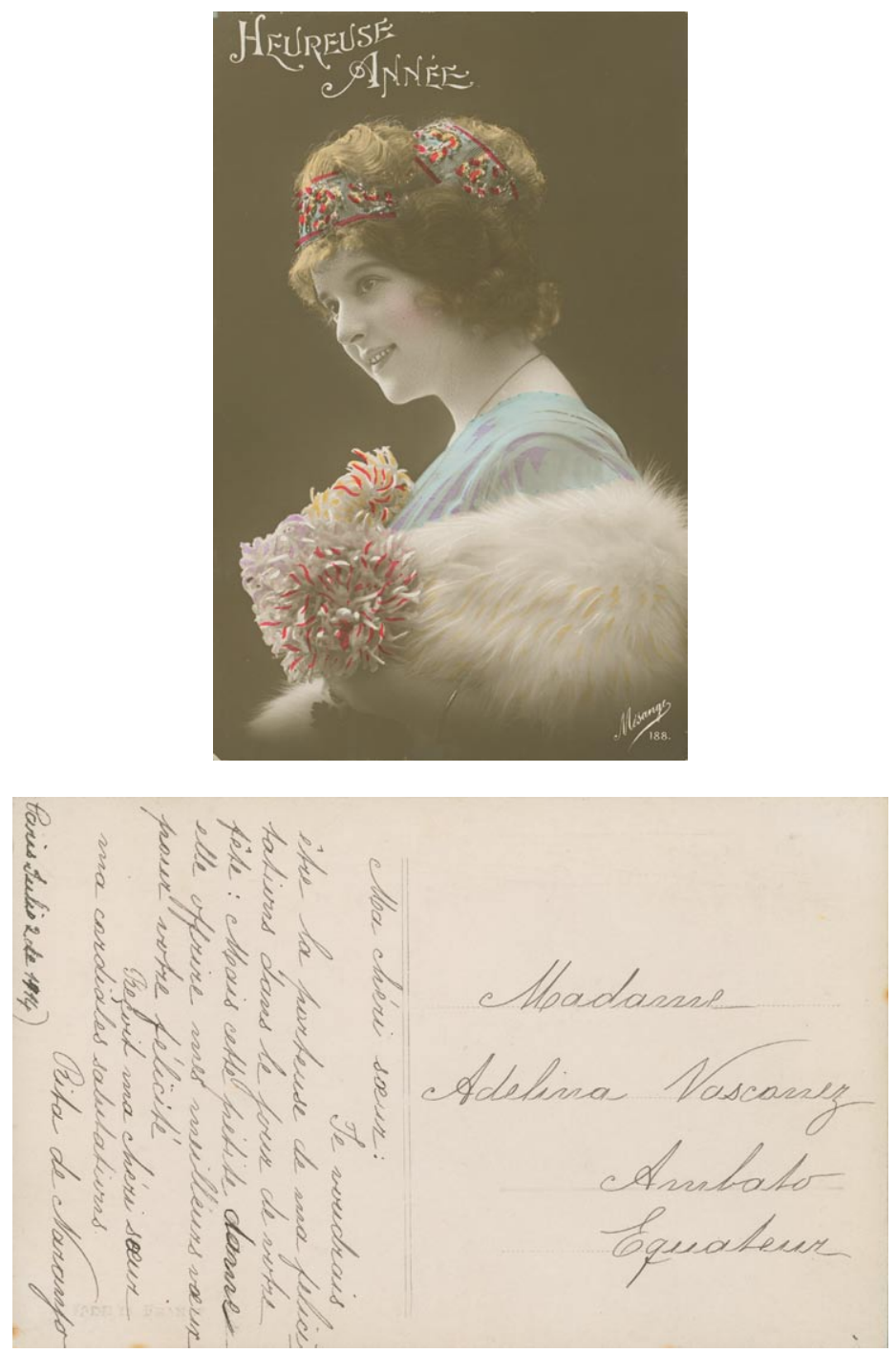

Figura 7

Anverso y reverso de tarjeta postal enviada por Rita de Naranjo a Adelina de Vásconez, desde París el 2 de julio de 1914.

Fuente: AHMCYP, Quito, Fondo Postales extranjeras, código de la postal: 84.F.19.179. 
Curiosamente, estos mensajes de Rita en lengua extranjera corresponden dentro del álbum al último año de las tarjetas fechadas y provenientes de Europa. No se sabe con exactitud hasta cuándo ella permaneció en el extranjero. ${ }^{62}$ No obstante, varios de estos envíos fueron realizados luego de la salida de su marido a Ecuador. Ángel informó a Adelina por postal sellada desde París el 16 de mayo de 1914 de su primer día de viaje en barco con dirección a Ecuador; lo hacía solo y, según lo indicado, Rita se había quedado en París. ${ }^{63}$ Rita, por su parte, escribió a su familia desde Vittel durante el mes de julio de 1914; en un par de sus mensajes, informó a su hermana y a su madre sobre su próxima vuelta a París, sin dar detalle alguno sobre fechas de permanencia en aquella ciudad o algún próximo desplazamiento. ${ }^{64}$ Sin embargo, un mes después, el 28 de agosto de 1914, se refirió en una nueva nota desde París a un «proyecto de viaje», del que Ángel les habría dado detalle. Según escribió: "Ya por las cartas de Angel [sabran de mi] proyecto de viaje, pidan mucho a la Virjen Santisima [sic] me guarde de todo mal y peligro». ${ }^{65}$

\section{Conclusiones}

Además de ser usadas como objetos de circulación y representación, las tarjetas postales sirvieron de instrumento para mantener a la distancia un hilo comunicativo constante. Durante los tres años que abarca el periodo de su actividad epistolar considerado en este estudio, las postales de la principal remitente de este intercambio, Rita de Naranjo, fueron vías para la correspondencia de noticias sobre visitas a diferentes luga-

62 A través de una postal de felicitación de Año Nuevo enviada por Mercedes (no incluye el apellido), el 1 de enero de 1926, a Rita con domicilio en Ambato, es deducible que su regreso habría sido durante el periodo entre la segunda mitad de 1914 y 1925, sin que exista envío suyo para ese tiempo. AHMCYP, Quito, Fondo postales extranjeras, código de la postal: 84.F.19.8.

${ }^{63}$ Postal enviada por Ángel Naranjo a Adelina de Vásconez. AHMCYP, Quito, Fondo postales extranjeras, código de la postal: 84.F.19.215.

${ }^{64}$ En su mensaje desde Vittel, del 28 de julio de 1914, Rita escribió a su hermana informándole de su viaje a París al día siguiente de su misiva. El mismo día y desde el mismo Vittel, Rita preparó otro mensaje, dirigido a su madre, señalándole su regreso a París el 29 de julio. AHMCYP, Quito, Fondo postales extranjeras, códigos de las postales respectivamente: 84.F.19.188, 84.F.19.192.

65 AHMCYP, Quito, Fondo postales extranjeras, códigos de las postales respectivamente: 84.F.19.188, 84.F.19.158. 
res, pero también para llamar la atención a sus familiares de la necesidad de mantener una comunicación continua. No se trataba únicamente de una mera convención sino, además, de un mecanismo para mantener este hilo comunicativo en actividad. Ello demuestra, por un lado, el valor afectivo que estaba implícito en el uso social de la correspondencia, aplicado normalmente a cartas, dentro del periodo analizado. Sin embargo, el contenido textual de estas postales mostró la importancia del mensaje corto, acorde a su formato, para transmitir brevemente, pero de manera efectiva, la necesidad de mantener viva la comunicación desde la distancia.

Otro uso de la tarjeta, destacable en el caso de Rita, es como un marcador de recorrido. Dentro de sus múltiples desplazamientos, la viajera iba declarando en varias de sus misivas los próximos destinos, creando así un tipo de relato de viaje que se adecuaba con las imágenes, como puntos visuales de los lugares visitados, y los textos en la narración de sus experiencias en cada uno de ellos.

El continuo envío durante los años de correspondencia fue creando, asimismo, una relación entre el viaje y la cotidianidad de Rita desde sus diferentes desplazamientos. Sus múltiples viajes y la gran presencia de sus mensajes en la colección de las tarjetas produjeron un «tiempo continuo» entre visitas, impresiones, pero a la vez de situaciones personales que se narran en el transcurso, tanto de novedad, sorpresa, nostalgia o problemas de salud. En contraste con su caso, en los mensajes que llegaban desde sus familiares o conocidos, poco se anuncia de eventos extraordinarios que atravesaran por sus vidas cotidianas, a excepción de problemas de salud de la madre de Ernesto Vásconez, cuñado de Rita. ${ }^{66}$

Es destacable, sin embargo y como ejemplo, los modos de ver el mundo que Rita iba transmitiendo como viajera y turista. Sin que exista un diario de viaje, las postales han servido de medio documental para la interpretación de su experiencia entre mundos desde lo visual y lo textual. Los textos cortos y fragmentados de los mensajes encierran en conjunto una narrativa que ha sido necesario reconstruir a través del entrelazamiento del contenido de las misivas.

El viaje no es solo una forma de desplazamiento físico y geográfico. Se trata también de todo lo que este integra en interacciones, impresio-

${ }^{66}$ Rita escribió desde Turín a José Ernesto Vásconez, el 24 de marzo de 1913, para saludarlo y desearle la recuperación de su madre. AHMCYP, Quito, Fondo postales extranjeras, postal 84.F.19.64. 
nes o apropiaciones directas e indirectas que producen entrecruzamientos culturales y, sobre todo, la experiencia de mundo y formación personal, como en el caso de Rita, gracias a lo que Europa podía ofrecerle. Si bien su manera de conocer un lugar fue, a primera vista, fragmentario, inmediato y superficial, como lo es la forma que transmite y encierra la tarjeta postal en sí misma - un instante, una vista, una visita - , la experiencia de Rita habría sido más profunda dentro de un proceso como sujeto en el aprendizaje, conocimiento y la propia experimentación consigo misma.

Junto al valor de uso y al representacional de la tarjeta postal analizada, es destacable el valor simbólico en la relación de la imagen con el texto que el usuario produce para sustituir una presencia. Se trata, así, de una «presencia simbólica» construida mediante una apropiación de elementos de la imagen para adaptarlos a la intención del mensaje textual. Gracias a las convenciones de saludos y de correspondencia, la tarjeta postal hizo las veces de esta presencia simbólica ante la ausencia física.

La mirada turística es fragmentada en la multiplicidad de lugares recorridos y de objetos que transitan de manera efímera en su experiencia turística. Esta fragmentariedad se expresa en la comunicación mediante la tarjeta postal; se trata de impresiones transmitidas rápidamente de manera textual. Si bien el formato de la tarjeta no permite una mayor extensión de detalles desde lo escrito, la imagen es usada a menudo para representar visualmente aquello que lo textual logra conseguirlo limitadamente.

El álbum representa otro elemento sumamente importante en este proceso investigativo por el sentido mnemónico que guarda el corpus. Existe un valor personal y familiar en el ejercicio de almacenamiento y conservación de todas las tarjetas que formaron parte del intercambio de correspondencia, así también la práctica de ordenamiento y colección para aquellas que fueron adquiridas con este propósito y que forman parte de este álbum. ${ }^{67}$ Este guarda la riqueza de ser objeto de memoria de un proceso vivido durante el viaje, de lo que encierra, en definitiva, la experiencia viajera. A la vez mantiene una ambivalencia, similar

67 Al relacionar al álbum fotográfico con un tipo de archivo, Armando Silva afirma la carga sentimental como también espontánea, privada e histórica que este contiene: características comparables al álbum de postales que incluye, además, el sentido de colección. Silva, 1998, p. 44. 
a la que Ebeling y Günzel otorgan al archivo en sí, ${ }^{68}$ entre el hecho de mostrar, como colección abierta, elementos importantes de un pasado, y de mantener ocultos aspectos que adquieren sentido y significado solamente a través del desciframiento y de su interpretación.

\section{Fuente}

AHMCYP, Archivo Histórico del Ministerio de Cultura y Patrimonio del Ecuador, Quito. Fondo: Postales extranjeras.

\section{Bibliografía}

AUGÉ, Marc, El viaje imposible. El turismo y sus imágenes, Gedisa, Barcelona, 2008.

APPADURAI, Arjun, La modernidad desbordada. Dimensiones culturales de la globalización, Trilce/Fondo de Cultura Económica, Montevideo/Buenos Aires, 2001.

BEDOYA, María Elena, «Las imágenes (nos) cuentan: Usos sociales de la fotografía en Quito», en SALAZAR PONCE, Betty, et al., El oficio de la fotografía en Quito, Fundación Museos de la Ciudad, Quito, 2011, pp. 58-83.

BENJAMIN, Walter, Libro de los Pasajes, Akal, Madrid, 2005a.

BENJAMIN, Walter, «Pequeña historia de la fotografía», en BENJAMIN, Walter, Sobre la fotografía, PRE-TEXTOS, Valencia, 2005b, pp. 21-53.

BERTONCELLO, Rodolfo, «Los imaginarios de espacios distantes a partir del turismo», en LINDÓN, Alicia y HIERNAUX, Daniel (dirs.), Geografías de lo imaginario, Anthropos/Universidad Autónoma Metropolitana-Iztapalapa, Barcelona/México, 2012, pp. 211-227.

BOYER, Marc, «El turismo en Europa, de la Edad Moderna al siglo XX», Historia Contemporánea, 25, 2002, 13-31. [Recuperado de internet: < http:// www.ehu.eus/ojs/index.php/HC/article/viewFile/5916/5596>. Última consulta: 17 de junio de 2019].

BREA, José Luis, Las tres eras de la imagen. Imagen-materia, film, e-image, Akal, Madrid, 2010.

BURGOS CUTHBERT, Guillermo, Valparaíso. Joya del Pacífico a través de sus postales de la época, Ricaaventura, Santiago de Chile, 2006.

${ }^{68}$ Según Ebeling y Günzel, el archivo tiene una función medial que se funda en la dialéctica del mostrar y ocultar, del incluir y excluir. Ebeling y Günzel, 2009, p. 14. 
María Ángela Cifuentes Guerra

CLIFFORD, James, Itinerarios transculturales, Gedisa, Barcelona, 1999.

EBELING, Knut y GÜNZEL, Stephan, «Einleitung», en EBELING, Knut y GÜNZEL, Stephan (eds.), Archivologie. Theorien des Archivs in Philosophie, Medien und Künsten, Kadmos, Berlín, 2009, pp. 7-26.

FREUND, Gisèle, La fotografía como documento social, Gustavo Gili, Barcelona, 1983.

GUEREÑA, Jean-Louis, «Imagen y memoria. La tarjeta postal a finales del siglo XIX y principios del siglo XX», Berceo, 149, 2005, pp. 35-58. [Recuperado de internet: <https://dialnet.unirioja.es/descarga/articulo/2229424.pdf>. Última consulta: 17 de junio de 2019].

IBARRA, Hernán, «Ambato, las ciudades y pueblos de la Sierra central ecuatoriana (1800-1930)», en KINGMAN GARCÉS, Eduardo (coord.), Ciudades de los Andes. Visión histórica y contemporánea, Ciudad, Quito, 1992, pp. 223-279. [Recuperado de internet: <http://www.flacsoandes.edu.ec/ libros/5714-opac>. Última consulta: 17 de junio de 2019].

LOIS, Carla y TRONCOSO, Claudia, «10x15. Las tarjetas postales como huellas en las prácticas de los turistas», Pasos, 15, 3, 2017, pp. 633-657. [Recuperado de internet: <http://ojsull.webs.ull.es/index.php/Revista/article/ view/882/pdf>. Última consulta: 17 de junio de 2019].

LÓPEZ HURTADO, Mariana, La tarjeta postal como documento. Estudio de usuarios y propuesta de un modelo analítico. Aplicación a la colección de postales del Ateneo de Madrid, Tesis doctoral, Universidad Complutense de Madrid, 2013. [Recuperado de internet: <https://eprints.ucm.es/23004/1/ T34790.pdf>. Última consulta: 17 de junio de 2019].

ONKEN, Hinnerk, «Visiones y visualizaciones: la nación en tarjetas postales sudamericanas a fines del siglo XIX y comienzos del siglo XX», Iberoamericana, XIV, 56, 2014, 47-69. [Recuperado de internet: <https://journals.iai. spk-berlin.de/index.php/iberoamericana/article/view/178>. Última consulta: 17 de junio de 2019].

PALOU RUBIO, Saida, «La ciudad fingida. Representaciones y memorias de la Barcelona turística», Pasos, 4, 1, 2006, 13-28. [Recuperado en internet: $<$ https://doi.org/10.25145/j.pasos.2006.04.002>. Última consulta: 17 de junio de 2019].

PASMIÑO YÁÑNEZ, Jorge, Álbum de familia. En tiempo de vacaciones, Universidad de Concepción, Concepción, 2016.

POOLE, Deborah, Raza y modernidad. Una economía visual del mundo andino de imágenes, Sur, Lima, 2000.

PRIAMO, Luis, «Fotografía y vida privada (1870-1930)», en DEVOTO, Fernando y MADERO, Marta, Historia de la vida privada en la Argentina, Taurus, Buenos Aires, tomo 2: La Argentina plural: 1870-1930, 1999, pp. 275-299. 
PUELlO SARABIA, Cielo Patricia, Álbumes de ciudad: Representaciones de procesos modernizantes en Cartagena de Indias y Santiago de Guayaquil a comienzos de siglo XX (1900-1930), Tesis de maestría, Universidad Andina Simón Bolívar - sede Ecuador, 2008. [Recuperado de internet: <http://hdl. handle.net/10644/488>. Última consulta: 17 de julio de 2019].

SANHUEZA, Carlos, «〈El problema de mi vida: ¡soy mujer!〉. Viaje, mujer y sociedad», en SAGREDO, Rafael y GAZMURI, Cristián, Historia de la vida privada en Chile, Taurus, Santiago de Chile, tomo 2: El Chile moderno. De 1840 a 1925, 2015, pp. 333-347.

SANTILLAN, Vilma Leonora, «La fotografía como creadora de la imagen de un destino turístico. Buenos Aires a través de sus tarjetas postales», Pasos, 8, 1, 2010, pp. 71-82. [Recuperado de internet: < http://www .redalyc.org/articulo. oa?id=88112836006 $>$. Última consulta: 17 de junio de 2019].

SCHWARZ, Gudrun, «Cuadros de viajes. Postales», en MARX, Ursula, et al., Archivos de Walter Benjamin. Imágenes, textos y dibujos, AECI-Círculo de Bellas Artes, Madrid, 2010, pp. 144-148.

SILVA, Armando, Álbum de familia. La imagen de nosotros mismos, Norma, Bogotá, 1998.

SONTAG, Susan, Sobre la fotografía, Edhasa, Barcelona, 1981.

VICUÑA, Manuel, La belle époque chilena. Alta sociedad y mujeres de élite en el cambio de siglo, Sudamericana, Santiago de Chile, 2001.

\section{Agradecimientos}

Agradezco a Rafael Van der Borght por su ayuda para entender los mensajes de tarjetas escritos en francés; igualmente, la amabilidad y colaboración del personal de la sección fotográfica del Archivo Histórico del Ministerio de Cultura y Patrimonio, en Quito.

\section{Datos de la autora}

María Ángela Cifuentes Guerra. Historiadora por la Pontificia Universidad Católica del Ecuador (PUCE), Quito; Dr. phil. por la Heinrich-Heine-Universität Düsseldorf-Alemania. Ha enseñado en: FLACSO-E, Universidad Andina Simón Bolívar-sede Ecuador, PUCE (Quito). En 2016 fue profesora invitada por la Universidad Centroamericana José Simeón Cañas (UCA), El Salvador. Actualmente, profesora en el Programa de Formación General, Universidad Diego Portales (UDP), Santiago de Chile. También, docente en Escuela de Historia, UAHC. Desde 2002, autora y colaboradora independiente de la obra Allgemeines Künstlerlexikon - AKL_ - editada en Alemania.

Sus líneas de investigación abordan campos de la historia y la cultura urbanas, artes visuales (énfasis en fotografía), historia y memoria. 


\section{Anexo 1. Lista de tarjetas postales dentro del álbum}

\begin{tabular}{|c|c|c|c|c|}
\hline Código tarjeta & Fecha & Motivo & Origen/Destino & Remitente/destinatario \\
\hline 84.F.19.1 & 12.12.1911 & $\begin{array}{l}\text { Guayaquil: bañistas } \\
\text { nocturnos }\end{array}$ & Guayaquil/Ambato & $\begin{array}{l}\text { Rita de Naranjo/ } \\
\text { Adelina de Vásconez }\end{array}$ \\
\hline 84.F.19.2 & 26.06.1912 & $\begin{array}{l}\text { Conmemorativa: } \\
\text { dama junto a lago. } \\
\text { Leyenda: «A vous de } \\
\text { tout coeur» }\end{array}$ & Londres/Ambato & $\begin{array}{l}\text { Rita/Adelina de } \\
\text { Vásconez }\end{array}$ \\
\hline 84.F.19.3 & 16.12.1909 & $\begin{array}{l}\text { Conmemorativa: } \\
\text { Retrato de estudio de } \\
\text { madre e hija }\end{array}$ & No señala/Ambato & $\begin{array}{l}\text { Desconocido/Rita de } \\
\text { Naranjo }\end{array}$ \\
\hline 84.F.19.4 & 14.12.1911 & $\begin{array}{l}\text { Lima: Estación del } \\
\text { F.C. Eléctrico a } \\
\text { Chorrillos }\end{array}$ & Lima/Ambato & $\begin{array}{l}\text { Rita/Adelina de } \\
\text { Vásconez }\end{array}$ \\
\hline 84.F.19.5 & 14.12 .1911 & $\begin{array}{l}\text { Malecón de } \\
\text { Chorrillos (Perú) } \\
\text { continuación tarjeta } \\
\text { anterior }\end{array}$ & Lima/Ambato & $\begin{array}{l}\text { Rita/Adelina de } \\
\text { Vásconez }\end{array}$ \\
\hline 84.F.19.6 & 12.1912 & $\begin{array}{l}\text { Guayaquil: } \\
\text { Monumento a Sucre }\end{array}$ & Guayaquil/Ambato & $\begin{array}{l}\text { Elisa (?)/Mercedes de } \\
\text { Ortega }\end{array}$ \\
\hline 84.F.19.7 & 22.04 .1913 & $\begin{array}{l}\text { Conmemorativa: } \\
\text { figura de niña con } \\
\text { corazón rojo }\end{array}$ & Ambato/París & $\begin{array}{l}\text { Adelina/Rita de } \\
\text { Naranjo }\end{array}$ \\
\hline 84.F.19.8 & 01.01 .1926 & $\begin{array}{l}\text { Conmemorativa: } \\
\text { figura femenina con } \\
\text { kimono }\end{array}$ & No señala/Ambato & $\begin{array}{l}\text { Mercedes (?)/Rita de } \\
\text { Naranjo }\end{array}$ \\
\hline 84.F.19.9 & 01.03.1912 & $\begin{array}{l}\text { Barcelona: Vista de } \\
\text { Tibidabo }\end{array}$ & Barcelona/Ambato & $\begin{array}{l}\text { Rita/Mercedes de } \\
\text { Ortega }\end{array}$ \\
\hline 84.F.19.10 & Sin fecha & $\begin{array}{l}\text { Bordeaux: Torre de } \\
\text { St. Michael }\end{array}$ & Bordeaux/Ambato & $\begin{array}{l}\text { Rita/Mercedes de } \\
\text { Ortega }\end{array}$ \\
\hline 84.F.19.11 & Sin fecha & Barcelona: Tibidabo & [Barcelona]/Ambato & $\begin{array}{l}\text { Rita/J. Ernesto } \\
\text { Vásconez }\end{array}$ \\
\hline 84.F.19.12 & Sin fecha & $\begin{array}{l}\text { Bordeaux: Jardín } \\
\text { público y estatua de } \\
\text { M. Lalanne }\end{array}$ & & En blanco \\
\hline
\end{tabular}


Postales, viaje y turismo: la experiencia de una viajera ecuatoriana a inicios del siglo XX

\begin{tabular}{|c|c|c|c|c|}
\hline Código tarjeta & Fecha & Motivo & Origen/Destino & Remitente/destinatario \\
\hline 84.F.19.13 & & $\begin{array}{l}\text { Bordeaux: Gare du } \\
\text { Midi }\end{array}$ & & En blanco \\
\hline 84.F.19.14 & 18.03 .1912 & $\begin{array}{l}\text { París: Hotel des } \\
\text { Invalides }\end{array}$ & París/Ambato & $\begin{array}{l}\text { Ángel Naranjo / } \\
\text { Ernesto Vásconez }\end{array}$ \\
\hline 84.F.19.15 & 06.1912 & $\begin{array}{l}\text { Londres: Escena de } \\
\text { Holborn viaduct. } \\
\text { Sobrepuestos los } \\
\text { retratos de los reyes }\end{array}$ & Londres/Ambato & $\begin{array}{l}\text { Rita/Ernesto } \\
\text { Vásconez }\end{array}$ \\
\hline 84.F.19.16 & & $\begin{array}{l}\text { Londres: catedral de } \\
\text { St. Paul }\end{array}$ & & En blanco \\
\hline 84.F.19.17 & $\begin{array}{l}\text { (ilegible) } \\
1912\end{array}$ & Londres: Hyde Park & Londres/Ambato & $\begin{array}{l}\text { Rita/Adelina de } \\
\text { Vásconez }\end{array}$ \\
\hline 84.F.19.18 & & $\begin{array}{l}\text { Londres: Tower } \\
\text { Bridge }\end{array}$ & & En blanco \\
\hline 84.F.19.19 & 16.06 .1912 & $\begin{array}{l}\text { Conmemorativa: } \\
\text { Anita, the living doll }\end{array}$ & Londres/Ambato & $\begin{array}{l}\text { Rita/Adelina de } \\
\text { Vásconez }\end{array}$ \\
\hline 84.F.19.20 & & $\begin{array}{l}\text { Londres: The Law } \\
\text { Courts }\end{array}$ & & En blanco \\
\hline 84.F.19.21 & Sin fecha & $\begin{array}{l}\text { Londres: Escena de } \\
\text { la exposición latino- } \\
\text { británica de } 1912\end{array}$ & Londres/Ambato & $\begin{array}{l}\text { Ángel Naranjo/ } \\
\text { Mercedes de Ortega }\end{array}$ \\
\hline 84.F.19.22 & 17.08 .1912 & $\begin{array}{l}\text { Londres: flip-flap en } \\
\text { la exposición latino- } \\
\text { británica de } 1912\end{array}$ & Londres/Ambato & $\begin{array}{l}\text { Rita/Adelina de } \\
\text { Vásconez }\end{array}$ \\
\hline 84.F.19.23 & 14.08 .1912 & $\begin{array}{l}\text { Londres: vista } \\
\text { panorámica de la } \\
\text { exposición desde el } \\
\text { flip-flap }\end{array}$ & Londres/Ambato & $\begin{array}{l}\text { Rita/Ernesto } \\
\text { Vásconez }\end{array}$ \\
\hline 84.F.19.24 & 14.08 .1912 & $\begin{array}{l}\text { Londres: El } \\
\text { Congress-Hall, en } \\
\text { la exposición latino- } \\
\text { británica }\end{array}$ & Londres/Ambato & $\begin{array}{l}\text { Rita/Adelina de } \\
\text { Vásconez }\end{array}$ \\
\hline 84.F.19.25 & 19.06.1912 & $\begin{array}{l}\text { Londres: edificio de } \\
\text { la Tate Gallery }\end{array}$ & Londres/Ambato & $\begin{array}{l}\text { Rita/Mercedes de } \\
\text { Ortega }\end{array}$ \\
\hline
\end{tabular}


María Ángela Cifuentes Guerra

\begin{tabular}{|c|c|c|c|c|}
\hline Código tarjeta & Fecha & Motivo & Origen/Destino & Remitente/destinatario \\
\hline 84.F.19.26 & 24.08 .1912 & $\begin{array}{l}\text { Londres: Corte de } \\
\text { honor, exposición } \\
\text { latino-británica }\end{array}$ & Londres/Ambato & $\begin{array}{l}\text { Rita/Adelina de } \\
\text { Vásconez }\end{array}$ \\
\hline 84.F.19.27 & 29.01 .1913 & $\begin{array}{l}\text { Bruselas: Museo de } \\
\text { Bellas Artes }\end{array}$ & Bruselas/Ambato & $\begin{array}{l}\text { Rita/Adelina de } \\
\text { Vásconez }\end{array}$ \\
\hline 84.F.19.28 & 11.03 .1913 & $\begin{array}{l}\text { Bruselas: La casa del } \\
\text { Rey }\end{array}$ & Bruselas/Ambato & $\begin{array}{l}\text { Rita/Mercedes de } \\
\text { Ortega }\end{array}$ \\
\hline 84.F.19.29 & 24.09 .1912 & $\begin{array}{l}\text { Londres: Frescos en } \\
\text { la casa de los Lords }\end{array}$ & Londres/Ambato & $\begin{array}{l}\text { Rita/Mercedes de } \\
\text { Ortega }\end{array}$ \\
\hline 84.F.19.30 & 11.09.1913 & $\begin{array}{l}\text { Amberes: Plaza de } \\
\text { la Gare }\end{array}$ & Bruselas/Ambato & $\begin{array}{l}\text { Rita/José E. } \\
\text { Vásconez }\end{array}$ \\
\hline 84.F.19.31 & Sin fecha & $\begin{array}{l}\text { Amberes: Estatua de } \\
\text { Brabo }\end{array}$ & Amberes/Ambato & $\begin{array}{l}\text { Rita/Adelina de } \\
\text { Vásconez }\end{array}$ \\
\hline 84.F.19.32 & 11.02 .1913 & $\begin{array}{l}\text { Amberes: Avenida } \\
\text { del Keyser }\end{array}$ & Bruselas/Ambato & $\begin{array}{l}\text { Rita/Adelina de } \\
\text { Vásconez }\end{array}$ \\
\hline 84.F.19.33 & 11.09.1913 & $\begin{array}{l}\text { Amberes: Vista de la } \\
\text { Gran Plaza }\end{array}$ & Bruselas/Ambato & $\begin{array}{l}\text { Rita/Mercedes de } \\
\text { Ortega }\end{array}$ \\
\hline 84.F.19.34 & & $\begin{array}{l}\text { Amberes: Edificio de } \\
\text { Stadhuis }\end{array}$ & & En blanco \\
\hline 84.F.19.35 & 15.02 .1913 & $\begin{array}{l}\text { Colonia: } \\
\text { Hohenzollerbrücke }\end{array}$ & Colonia/Ambato & $\begin{array}{l}\text { Rita/Adelina de } \\
\text { Vásconez }\end{array}$ \\
\hline 84.F.19.36 & 28.02 .1913 & $\begin{array}{l}\text { Berlín: Estación de } \\
\text { Potsdam }\end{array}$ & Berlín/Ambato & $\begin{array}{l}\text { Rita/Adelina de } \\
\text { Vásconez }\end{array}$ \\
\hline 84.F.19.37 & 02.03 .1913 & Bruselas: City Hall & Bruselas/Ambato & $\begin{array}{l}\text { Rita/José E. } \\
\text { Vásconez }\end{array}$ \\
\hline 84.F.19.38 & & $\begin{array}{l}\text { Berlín: Museo del } \\
\text { Kaiser Friedrich }\end{array}$ & & En blanco \\
\hline 84.F.19.39 & 24.02 .1913 & $\begin{array}{l}\text { Berlín: Monumento } \\
\text { al Kaiser Wilhelm }\end{array}$ & Berlín/Ambato & $\begin{array}{l}\text { Rita/Mercedes de } \\
\text { Ortega }\end{array}$ \\
\hline 84.F.19.40 & 15.02 .1913 & Colonia: Catedral & Colonia/Ambato & $\begin{array}{l}\text { Rita/ José E. } \\
\text { Vásconez }\end{array}$ \\
\hline 84.F.19.41 & & $\begin{array}{l}\text { Berlín: Puerta de } \\
\text { Brandenburgo }\end{array}$ & & En blanco \\
\hline
\end{tabular}


Postales, viaje y turismo: la experiencia de una viajera ecuatoriana a inicios del siglo XX

\begin{tabular}{|c|c|c|c|c|}
\hline Código tarjeta & Fecha & Motivo & Origen/Destino & Remitente/destinatario \\
\hline 84.F.19.42 & Sin fecha & $\begin{array}{l}\text { Berlín: Puente del } \\
\text { castillo }\end{array}$ & Berlín/Ambato & $\begin{array}{l}\text { Rita/Adelina de } \\
\text { Vásconez }\end{array}$ \\
\hline 84.F.19.43 & & Colonia: Catedral & & En blanco \\
\hline 84.F.19.44 & 24.02 .1913 & $\begin{array}{l}\text { Berlín: Burgstraße } \\
\text { con catedral y castillo }\end{array}$ & Berlín/Ambato & $\begin{array}{l}\text { Rita/Adelina de } \\
\text { Vásconez }\end{array}$ \\
\hline 84.F.19.45 & & $\begin{array}{l}\text { Berlín: Monumento } \\
\text { al emperador } \\
\text { Wilhelm }\end{array}$ & & En blanco \\
\hline 84.F.19.46 & & Colonia: Catedral & & En blanco \\
\hline 84.F.19.47 & & $\begin{array}{l}\text { Colonia: vista } \\
\text { panorámica }\end{array}$ & & En blanco \\
\hline 84.F.19.48 & 04.03 .1913 & $\begin{array}{l}\text { Viena: Museo de } \\
\text { Historia del Arte }\end{array}$ & Viena/Ambato & $\begin{array}{l}\text { Rita/Mercedes de } \\
\text { Ortega }\end{array}$ \\
\hline 84.F.19.49 & 15.09 .1913 & Colonia: Catedral & Colonia/Ambato & $\begin{array}{l}\text { Rita/Mercedes de } \\
\text { Ortega }\end{array}$ \\
\hline 84.F.19.50 & 04.03 .1913 & $\begin{array}{l}\text { Viena: Castillo } \\
\text { Schönbrunn }\end{array}$ & Viena/Ambato & $\begin{array}{l}\text { Rita/Adelina de } \\
\text { Vásconez }\end{array}$ \\
\hline 84.F.19.51 & Sin fecha & Milán: Catedral & [Milán]/Ambato & $\begin{array}{l}\text { Rita/Adelina de } \\
\text { Vásconez }\end{array}$ \\
\hline 84.F.19.52 & 13.03 .1913 & $\begin{array}{l}\text { Venecia: Puente de } \\
\text { los suspiros }\end{array}$ & Venecia/Ambato & $\begin{array}{l}\text { Rita/Adelina de } \\
\text { Vásconez }\end{array}$ \\
\hline 84.F.19.53 & 15.03 .1913 & Milán: Catedral & Milán/Ambato & $\begin{array}{l}\text { Rita/Mercedes de } \\
\text { Ortega }\end{array}$ \\
\hline 84.F.19.54 & Sin fecha & $\begin{array}{l}\text { Milán: Plaza y teatro } \\
\text { della Scala }\end{array}$ & $\begin{array}{l}\text { Posible } \\
\text { continuación de otra } \\
\text { tarjeta. }\end{array}$ & Sin destinatario \\
\hline 84.F.19.55 & 17.03 .1913 & $\begin{array}{l}\text { Milán: Pinacoteca de } \\
\text { Brera. Reproducción } \\
\text { cuadro de Rafael }\end{array}$ & Milán/Ambato & $\begin{array}{l}\text { Rita/José E. } \\
\text { Vásconez }\end{array}$ \\
\hline 84.F.19.56 & 19.03 .1913 & $\begin{array}{l}\text { Milán: Interior Teatro } \\
\text { de la Scala }\end{array}$ & $\begin{array}{l}\text { Milán/Ambato } \\
\text { Continuación de } \\
\text { otra tarjeta }\end{array}$ & $\begin{array}{l}\text { Firma Rita, sin } \\
\text { destinatario }\end{array}$ \\
\hline 84.F.19.57 & Sin fecha & $\begin{array}{l}\text { Venecia: Panorama } \\
\text { del mar }\end{array}$ & [Venecia]/Ambato & $\begin{array}{l}\text { Rita/José E. } \\
\text { Vásconez }\end{array}$ \\
\hline
\end{tabular}


María Ángela Cifuentes Guerra

\begin{tabular}{|c|c|c|c|c|}
\hline Código tarjeta & Fecha & Motivo & Origen/Destino & Remitente/destinatario \\
\hline 84.F.19.58 & 15.03.1913 & Milán: Catedral & Milán/Ambato & $\begin{array}{l}\text { Rita/Mercedes de } \\
\text { Ortega }\end{array}$ \\
\hline 84.F.19.59 & Sin fecha & $\begin{array}{l}\text { Venecia: Iglesia de } \\
\text { San Marco }\end{array}$ & [Venecia]/Ambato & $\begin{array}{l}\text { Rita/Mercedes de } \\
\text { Ortega }\end{array}$ \\
\hline 84.F.19.60 & 26.03 .1913 & $\begin{array}{l}\text { Génova: Estación } \\
\text { principal y panorama } \\
\text { del puerto }\end{array}$ & Génova/Ambato & $\begin{array}{l}\text { Rita/Adelina de } \\
\text { Vásconez }\end{array}$ \\
\hline 84.F.19.61 & 28.03 .1913 & $\begin{array}{l}\text { Florencia: fachada de } \\
\text { la catedral }\end{array}$ & Florencia/Ambato & $\begin{array}{l}\text { Rita/Adelina de } \\
\text { Vásconez }\end{array}$ \\
\hline 84.F.19.62 & 16.04 .1913 & $\begin{array}{l}\text { Génova: plaza } \\
\text { principal, monumento } \\
\text { al Duque de Galliera }\end{array}$ & Génova/Ambato & $\begin{array}{l}\text { Rita/Adelina de } \\
\text { Vásconez }\end{array}$ \\
\hline 84.F.19.63 & 26.03 .1913 & $\begin{array}{l}\text { Génova: plaza } \\
\text { Corvetto }\end{array}$ & Génova/Ambato & $\begin{array}{l}\text { Rita/Mercedes de } \\
\text { Ortega }\end{array}$ \\
\hline 84.F.19.64 & 24.03 .1913 & $\begin{array}{l}\text { Turín: monumento a } \\
\text { Frejus }\end{array}$ & Turín/Ambato & $\begin{array}{l}\text { Rita/José E. } \\
\text { Vásconez }\end{array}$ \\
\hline 84.F.19.65 & 24.03 .1913 & $\begin{array}{l}\text { Turín: castillo de } \\
\text { Valentino }\end{array}$ & Turín/Ambato & $\begin{array}{l}\text { Rita/Mercedes de } \\
\text { Ortega }\end{array}$ \\
\hline 84.F.19.66 & 24.03 .1913 & $\begin{array}{l}\text { Turín: Basílica de } \\
\text { Superga }\end{array}$ & Turín/Ambato & $\begin{array}{l}\text { Rita/Adelina de } \\
\text { Vásconez }\end{array}$ \\
\hline 84.F.19.67 & & $\begin{array}{l}\text { Turín: Mole } \\
\text { Antonelliana }\end{array}$ & & En blanco \\
\hline 84.F.19.68 & & $\begin{array}{l}\text { Turín: fachada de la } \\
\text { Estación Central }\end{array}$ & & En blanco \\
\hline 84.F.19.69 & Sin fecha & $\begin{array}{l}\text { Milán: plaza de la } \\
\text { Catedral }\end{array}$ & $\begin{array}{l}\text { Continuación de } \\
\text { otra postal }\end{array}$ & $\begin{array}{l}\text { Rita/Mercedes de } \\
\text { Ortega }\end{array}$ \\
\hline 84.F.19.70 & & $\begin{array}{l}\text { Florencia: Plaza de la } \\
\text { Signoria }\end{array}$ & & En blanco \\
\hline 84.F.19.71 & & $\begin{array}{l}\text { Florencia: Plaza de } \\
\text { Miguel Ángel }\end{array}$ & & En blanco \\
\hline 84.F.19.72 & 27.03 .1913 & $\begin{array}{l}\text { Pisa: vista } \\
\text { panorámica }\end{array}$ & Pisa/Ambato & $\begin{array}{l}\text { Rita/Adelina de } \\
\text { Vásconez }\end{array}$ \\
\hline 84.F.19.73 & 27.03.1913 & $\begin{array}{l}\text { Pisa: la Torre } \\
\text { (Campanile) }\end{array}$ & Pisa/Ambato & $\begin{array}{l}\text { Rita/Adelina de } \\
\text { Vásconez }\end{array}$ \\
\hline
\end{tabular}


Postales, viaje y turismo: la experiencia de una viajera ecuatoriana a inicios del siglo XX

\begin{tabular}{|c|c|c|c|c|}
\hline Código tarjeta & Fecha & Motivo & Origen/Destino & Remitente/destinatario \\
\hline 84.F.19.74 & 27.03 .1913 & $\begin{array}{l}\text { Pisa: Catedral y } \\
\text { Campanile }\end{array}$ & Pisa/Ambato & $\begin{array}{l}\text { Rita/Mercedes de } \\
\text { Ortega }\end{array}$ \\
\hline 84.F.19.75 & 12.04.1913 & $\begin{array}{l}\text { Roma: Basílica de } \\
\text { San Pablo }\end{array}$ & Roma/Ambato & $\begin{array}{l}\text { Rita/Mercedes de } \\
\text { Ortega }\end{array}$ \\
\hline 84.F.19.76 & 23.04 .1913 & Lourdes: la Gruta & Lourdes/Ambato & $\begin{array}{l}\text { Rita/Adelina de } \\
\text { Vásconez }\end{array}$ \\
\hline 84.F.19.77 & Sin fecha & $\begin{array}{l}\text { Roma: claustro de la } \\
\text { Basílica de San Pablo }\end{array}$ & $\begin{array}{l}\text { Continuación una } \\
\text { tarjeta anterior }\end{array}$ & Rita/desconocido \\
\hline 84.F.19.78 & 04.04 .1913 & $\begin{array}{l}\text { Roma: Arco de } \\
\text { Constantino }\end{array}$ & Roma/Ambato & Rita/José Vásconez \\
\hline 84.F.19.79 & & $\begin{array}{l}\text { Reproducción A. von } \\
\text { Dyck: la crucifixión } \\
\text { de Nuestro Señor }\end{array}$ & & En blanco \\
\hline 84.F.19.80 & Sin fecha & $\begin{array}{l}\text { Roma: Fontana di } \\
\text { Trevi }\end{array}$ & [Roma]/Ambato & $\begin{array}{l}\text { Rita/Adelina de } \\
\text { Vásconez }\end{array}$ \\
\hline 84.F.19.81 & Sin fecha & $\begin{array}{l}\text { Roma: vista general } \\
\text { de San Pedro }\end{array}$ & [Roma]/Ambato & $\begin{array}{l}\text { Rita/Adelina de } \\
\text { Vásconez }\end{array}$ \\
\hline 84.F.19.82 & 12.04 .1913 & $\begin{array}{l}\text { Roma: interior de San } \\
\text { Pedro }\end{array}$ & Roma/Ambato & $\begin{array}{l}\text { Rita/Adelina de } \\
\text { Vásconez }\end{array}$ \\
\hline 84.F.19.83 & Sin fecha & $\begin{array}{l}\text { Roma: fachada de S. } \\
\text { Giovanni }\end{array}$ & & $\begin{array}{l}\text { Rita/Ernesto } \\
\text { Vásconez }\end{array}$ \\
\hline 84.F.19.84 & & $\begin{array}{l}\text { Roma: La Scala } \\
\text { Santa }\end{array}$ & & En blanco \\
\hline 84.F.19.85 & Sin fecha & $\begin{array}{l}\text { Lourdes: paisaje y } \\
\text { Virgen Coronada }\end{array}$ & $\begin{array}{l}\text { Posible } \\
\text { continuación de otra } \\
\text { tarjeta }\end{array}$ & $\begin{array}{l}\text { Rita/no señala } \\
\text { destinatario }\end{array}$ \\
\hline 84.F.19.86 & & Roma: San Pedro & & En blanco \\
\hline 84.F.19.87 & 04.04 .1913 & $\begin{array}{l}\text { Roma: Pio X } \\
\text { paseando en el jardín } \\
\text { del Vaticano }\end{array}$ & Roma/Ambato & $\begin{array}{l}\text { Rita/Mercedes de } \\
\text { Ortega }\end{array}$ \\
\hline 84.F.19.88 & & Retrato de Pio X & & En blanco \\
\hline 84.F.19.89 & & $\begin{array}{l}\text { Roma: plaza de San } \\
\text { Pedro }\end{array}$ & & En blanco \\
\hline
\end{tabular}


María Ángela Cifuentes Guerra

\begin{tabular}{|c|c|c|c|c|}
\hline Código tarjeta & Fecha & Motivo & Origen/Destino & Remitente/destinatario \\
\hline 84.F.19.90 & & $\begin{array}{l}\text { Roma: Basílica de } \\
\text { San Pablo }\end{array}$ & & En blanco \\
\hline 84.F.19.91 & Sin fecha & $\begin{array}{l}\text { Barcelona: Tibidabo, } \\
\text { plaza de Estación }\end{array}$ & [Barcelona]/Ambato & Rita/Rosa Salas \\
\hline 84.F.19.92 & 01.03 .1912 & $\begin{array}{l}\text { Barcelona: Tibidabo: } \\
\text { edificio de la cúspide }\end{array}$ & Sin dato/Ambato & $\begin{array}{l}\text { Ángel Naranjo/ } \\
\text { Ernesto Vásconez }\end{array}$ \\
\hline 84.F.19.93 & 21.05 .1911 & $\begin{array}{l}\text { Conmemorativa: } \\
\text { figura de ángel con } \\
\text { alas }\end{array}$ & Ambato/Ambato & Victoria T./Rita \\
\hline 84.F.19.94 & 02.08 .1910 & $\begin{array}{l}\text { Conmemorativa: } \\
\text { retrato niño con } \\
\text { flores }\end{array}$ & Ambato/Ambato & $\begin{array}{l}\text { Reinaldo Salas/Sr. } \\
\text { Naranjo }\end{array}$ \\
\hline 84.F.19.95 & 19.01 .1912 & $\begin{array}{l}\text { Santiago de Chile: } \\
\text { Parque Forestal }\end{array}$ & Santiago/Ambato & $\begin{array}{l}\text { Rita/Ernesto } \\
\text { Vásconez }\end{array}$ \\
\hline 84.F.19.96 & 22.02 .1912 & $\begin{array}{l}\text { Tenerife: Fiesta al } \\
\text { Valle Guerra }\end{array}$ & España/Ambato & $\begin{array}{l}\text { Rita/Mercedes de } \\
\text { Ortega }\end{array}$ \\
\hline 84.F.19.97 & Sin fecha & $\begin{array}{l}\text { Roma: Iglesia de San } \\
\text { Pablo }\end{array}$ & $\begin{array}{l}\text { Continuación de } \\
\text { otra tarjeta }\end{array}$ & Rita/sin destinatario \\
\hline 84.F.19.98 & Sin fecha & $\begin{array}{l}\text { Foto de un altar } \\
\text { (recuerdo) }\end{array}$ & & $\begin{array}{l}\text { Recuerdo de } \\
\text { los alumnos del } \\
\text { Aspirantado San } \\
\text { José a las Madres } \\
\text { Apostólicas }\end{array}$ \\
\hline 84.F.19.99 & & $\begin{array}{l}\text { Roma: Fontana di } \\
\text { Trevi }\end{array}$ & & En blanco \\
\hline 84.F.19.100 & & Roma: Foro Romano & & En blanco \\
\hline 84.F.19.101 & & Roma: Foro Trajano & & En blanco \\
\hline 84.F.19.102 & & Roma: Plaza Colonna & & En blanco \\
\hline 84.F.19.103 & 27.03 .1913 & Pisa: Baptisterio & [Pisa]/Ambato & $\begin{array}{l}\text { Rita/Ernesto } \\
\text { Vásconez }\end{array}$ \\
\hline 84.F.19.104 & & $\begin{array}{l}\text { Roma: Plaza de San } \\
\text { Pedro }\end{array}$ & & En blanco \\
\hline 84.F.19.105 & & $\begin{array}{l}\text { Roma: S. Giovanni } \\
\text { en Laterano }\end{array}$ & & En blanco \\
\hline
\end{tabular}


Postales, viaje y turismo: la experiencia de una viajera ecuatoriana a inicios del siglo XX

\begin{tabular}{|c|c|c|c|c|}
\hline Código tarjeta & Fecha & Motivo & Origen/Destino & Remitente/destinatario \\
\hline 84.F.19.106 & 09.07.1914 & $\begin{array}{l}\text { Vittel: Escena } \\
\text { urbana: Autour du } \\
\text { Kiosque à Musique }\end{array}$ & Vittel/Ambato & $\begin{array}{l}\text { Rita/Mercedes de } \\
\text { Ortega }\end{array}$ \\
\hline 84.F.19.107 & & $\begin{array}{l}\text { Roma: Basílica de } \\
\text { San Pedro }\end{array}$ & & En blanco \\
\hline 84.F.19.108 & & Roma: San Pedro & & En blanco \\
\hline 84.F.19.109 & 28.03 .1913 & $\begin{array}{l}\text { Florencia: Pórtico de } \\
\text { los Uffizi }\end{array}$ & Florencia/Ambato & $\begin{array}{l}\text { Rita/Mercedes de } \\
\text { Ortega }\end{array}$ \\
\hline 84.F.19.110 & & $\begin{array}{l}\text { Roma: Claustro } \\
\text { basílica de San Pablo }\end{array}$ & & En blanco \\
\hline 84.F.19.111 & & $\begin{array}{l}\text { Roma: Arco de } \\
\text { Constantino }\end{array}$ & & En blanco \\
\hline 84.F.19.112 & & $\begin{array}{l}\text { Florencia: Palacio } \\
\text { Pretorio }\end{array}$ & & En blanco \\
\hline 84.F.19.113 & & Roma: Arco de Tito & & En blanco \\
\hline 84.F.19.114 & & $\begin{array}{l}\text { Roma: Templo de } \\
\text { Vesta con fuente }\end{array}$ & & En blanco \\
\hline 84.F.19.115 & & $\begin{array}{l}\text { Roma: vía Appia } \\
\text { nueva, acueducto de } \\
\text { Claudio }\end{array}$ & & En blanco \\
\hline 84.F.19.116 & & $\begin{array}{l}\text { Vista general del } \\
\text { puente y castillo S. } \\
\text { Angelo }\end{array}$ & & En blanco \\
\hline 84.F.19.117 & 04.04 .1913 & $\begin{array}{l}\text { Roma: Campidoglio- } \\
\text { palacio Senatorio }\end{array}$ & Roma/Ambato & $\begin{array}{l}\text { Rita/Adelina de } \\
\text { Vásconez }\end{array}$ \\
\hline 84.F.19.118 & 24.09 .1913 & $\begin{array}{l}\text { Conmemorativa: } \\
\text { figura mujer besando } \\
\text { crucifijo }\end{array}$ & París/Ambato & $\begin{array}{l}\text { Rita/Mercedes de } \\
\text { Ortega }\end{array}$ \\
\hline 84.F.19.119 & & $\begin{array}{l}\text { Roma: Vía Appia } \\
\text { nueva, acueducto de } \\
\text { Claudio }\end{array}$ & & En blanco \\
\hline 84.F.19.120 & & $\begin{array}{l}\text { Roma: Tumba de } \\
\text { Cecilia Metella }\end{array}$ & & En blanco \\
\hline
\end{tabular}


María Ángela Cifuentes Guerra

\begin{tabular}{|c|c|c|c|c|}
\hline Código tarjeta & Fecha & Motivo & Origen/Destino & Remitente/destinatario \\
\hline 84.F.19.121 & Sin fecha & $\begin{array}{l}\text { Conmemorativa: } \\
\text { Bonne Annèe. Retrato } \\
\text { coloreado de niño } \\
\text { envuelto en rosas }\end{array}$ & Sin dato/Ambato & $\begin{array}{l}\text { Rita/Mercedes de } \\
\text { Ortega }\end{array}$ \\
\hline 84.F.19.122 & & $\begin{array}{l}\text { Roma: Puerta de S. } \\
\text { Pablo y pirámide de } \\
\text { Cayo Cestio }\end{array}$ & & En blanco \\
\hline 84.F.19.123 & 01.05 .1913 & París: la Ópera & París/Ambato & $\begin{array}{l}\text { Rita/Adelina de } \\
\text { Vásconez }\end{array}$ \\
\hline 84.F.19.124 & 24.05 .1913 & París: el Panteón & París/Ambato & $\begin{array}{l}\text { Rita/Adelina de } \\
\text { Vásconez }\end{array}$ \\
\hline 84.F.19.125 & 11.07 .1913 & París: palacio Royal & París/Ambato & $\begin{array}{l}\text { Rita/Adelina de } \\
\text { Vásconez }\end{array}$ \\
\hline 84.F.19.126 & 01.05 .1913 & $\begin{array}{l}\text { París: palacio de } \\
\text { Luxemburgo }\end{array}$ & París/Ambato & Rita/José Vásconez \\
\hline 84.F.19.127 & 15.02.1914 & París: el gran carrusel & París/Ambato & $\begin{array}{l}\text { Rita/Adelina de } \\
\text { Vásconez }\end{array}$ \\
\hline 84.F.19.128 & 13.03.1914 & París: el Trocadero & París/Ambato & $\begin{array}{l}\text { Rita/Adelina de } \\
\text { Vásconez }\end{array}$ \\
\hline 84.F.19.129 & 20.07.1913 & Versalles: el Chateau & Versalles/Ambato & $\begin{array}{l}\text { Rita/Adelina de } \\
\text { Vásconez }\end{array}$ \\
\hline 84.F.19.130 & 20.07 .1913 & $\begin{array}{l}\text { Versalles: fuente y } \\
\text { grandes fuegos }\end{array}$ & Versalles/Ambato & $\begin{array}{l}\text { Rita/Ernesto } \\
\text { Vásconez }\end{array}$ \\
\hline 84.F.19.131 & 20.07.1913 & $\begin{array}{l}\text { Versalles: vista } \\
\text { general de los } \\
\text { jardines del palacio } \\
\text { de Versalles }\end{array}$ & Versalles/Ambato & $\begin{array}{l}\text { Rita/Mercedes de } \\
\text { Ortega }\end{array}$ \\
\hline 84.F.19.132 & 19.04 .1914 & Saint Cloud: parque & $\begin{array}{l}\text { Saint Cloud/ } \\
\text { Ambato }\end{array}$ & $\begin{array}{l}\text { Rita/Adelina de } \\
\text { Vásconez }\end{array}$ \\
\hline 84.F.19.133 & 27.09.1913 & París: Torre Eiffel & París/Ambato & $\begin{array}{l}\text { Rita/Mercedes de } \\
\text { Ortega }\end{array}$ \\
\hline 84.F.19.134 & 05.10 .1913 & $\begin{array}{l}\text { St. Germain en Laye: } \\
\text { palacio }\end{array}$ & $\begin{array}{l}\text { St. Germain/ } \\
\text { Ambato }\end{array}$ & $\begin{array}{l}\text { Rita/Adelina de } \\
\text { Vásconez }\end{array}$ \\
\hline
\end{tabular}


Postales, viaje y turismo: la experiencia de una viajera ecuatoriana a inicios del siglo XX

\begin{tabular}{|c|c|c|c|c|}
\hline Código tarjeta & Fecha & Motivo & Origen/Destino & Remitente/destinatario \\
\hline 84.F.19.135 & 05.10 .1913 & $\begin{array}{l}\text { St. Germain en Laye: } \\
\text { jardines }\end{array}$ & $\begin{array}{l}\text { St. Germain/ } \\
\text { Ambato }\end{array}$ & $\begin{array}{l}\text { Rita/Mercedes de } \\
\text { Ortega }\end{array}$ \\
\hline 84.F.19.136 & 30.05 .1913 & $\begin{array}{l}\text { Maison de Santé de } \\
\text { la Rue Blomét }\end{array}$ & París/Ambato & $\begin{array}{l}\text { Rita/Ernesto } \\
\text { Vásconez }\end{array}$ \\
\hline 84.F.19.137 & 05.10 .1913 & $\begin{array}{l}\text { St. Germain en Laye: } \\
\text { Le Rond point des } \\
\text { Roses }\end{array}$ & $\begin{array}{l}\text { St. Germain/ } \\
\text { Ambato }\end{array}$ & $\begin{array}{l}\text { Rita/Ernesto } \\
\text { Vásconez }\end{array}$ \\
\hline 84.F.19.138 & 21.09 .1913 & $\begin{array}{l}\text { Le Celle Saint Cloud: } \\
\text { Gare de Bougival }\end{array}$ & Bougival/Ambato & $\begin{array}{l}\text { Rita/Adelina de } \\
\text { Vásconez }\end{array}$ \\
\hline 84.F.19.139 & 07.06 .1913 & $\begin{array}{l}\text { París: Colonne } \\
\text { Vendome }\end{array}$ & París/Ambato & $\begin{array}{l}\text { Rita/Adelina de } \\
\text { Vásconez }\end{array}$ \\
\hline 84.F.19.140 & 29.10 .1913 & $\begin{array}{l}\text { Bougival: } \\
\text { Restaurante en lago }\end{array}$ & París/Ambato & $\begin{array}{l}\text { Rita/Adelina de } \\
\text { Vásconez }\end{array}$ \\
\hline 84.F.19.141 & 22.06 .1913 & Castillo de Chantilly & Sin dato/Ambato & $\begin{array}{l}\text { Rita/Adelina de } \\
\text { Vásconez }\end{array}$ \\
\hline 84.F.19.142 & 27.09 .1913 & $\begin{array}{l}\text { París: aeroplano } \\
\text { sobre torre Eiffel }\end{array}$ & París/Ambato & $\begin{array}{l}\text { Rita/Adelina de } \\
\text { Vásconez }\end{array}$ \\
\hline 84.F.19.143 & 30.05 .1913 & $\begin{array}{l}\text { Maison de Santé de } \\
\text { la Rue Blomét }\end{array}$ & París/Ambato & $\begin{array}{l}\text { Rita/Mercedes de } \\
\text { Ortega }\end{array}$ \\
\hline 84.F.19.144 & 30.05 .1913 & $\begin{array}{l}\text { Maison de Santé de } \\
\text { la Rue Blomét }\end{array}$ & París/Ambato & $\begin{array}{l}\text { Rita/Adelina de } \\
\text { Vásconez }\end{array}$ \\
\hline 84.F.19.145 & 03.07 .1914 & $\begin{array}{l}\text { Conmemorativa: } \\
\text { niños en jardín }\end{array}$ & París/Ambato & $\begin{array}{l}\text { Rita/Ernesto } \\
\text { Vásconez }\end{array}$ \\
\hline 84.F.19.146 & 18.09 .1913 & París: el Gran Palacio & París/Ambato & $\begin{array}{l}\text { Rita/Adelina de } \\
\text { Vásconez }\end{array}$ \\
\hline 84.F.19.147 & & $\begin{array}{l}\text { Escena histórica: } \\
\text { despedida de } \\
\text { Napoleón a la } \\
\text { guardia imperial. } \\
\text { Fontainebleau }\end{array}$ & & En blanco \\
\hline 84.F.19.148 & 30.06 .1913 & $\begin{array}{l}\text { Fontainebleau: Acta } \\
\text { de abdicación de } \\
\text { Napoleón }\end{array}$ & París/Ambato & $\begin{array}{l}\text { Rita/Ernesto } \\
\text { Vásconez }\end{array}$ \\
\hline
\end{tabular}


María Ángela Cifuentes Guerra

\begin{tabular}{|c|c|c|c|c|}
\hline Código tarjeta & Fecha & Motivo & Origen/Destino & Remitente/destinatario \\
\hline 84.F.19.149 & & $\begin{array}{l}\text { Fontainebleau: } \\
\text { Representación de la } \\
\text { abdicación }\end{array}$ & & En blanco \\
\hline 84.F.19.150 & 29.06 .1913 & $\begin{array}{l}\text { Palacio de } \\
\text { Fontainebleau: vista } \\
\text { del palacio y jardín }\end{array}$ & Sin dato/Ambato & $\begin{array}{l}\text { Rita/Mercedes de } \\
\text { Ortega }\end{array}$ \\
\hline 84.F.19.151 & & $\begin{array}{l}\text { Palacio de } \\
\text { Fontainebleau: } \\
\text { oficina de trabajo de } \\
\text { Napoleón }\end{array}$ & & En blanco \\
\hline 84.F.19.152 & 29.06.1913 & $\begin{array}{l}\text { Palacio de } \\
\text { Fontainebleau }\end{array}$ & Sin dato/Ambato & $\begin{array}{l}\text { Rita/Adelina de } \\
\text { Vásconez }\end{array}$ \\
\hline 84.F.19.153 & 30.06 .1913 & $\begin{array}{l}\text { Palacio de } \\
\text { Fontainebleau: } \\
\text { reproducción de «The } \\
\text { Seller of Loves», de } \\
\text { J.M. Vien }\end{array}$ & París/Ambato & $\begin{array}{l}\text { Rita/Adelina de } \\
\text { Vásconez }\end{array}$ \\
\hline 84.F.19.154 & & Menton & & En blanco \\
\hline 84.F.19.155 & & $\begin{array}{l}\text { Maison de Santé de } \\
\text { la Rue Blomét }\end{array}$ & & En blanco \\
\hline 84.F.19.156 & 24.04 .1914 & $\begin{array}{l}\text { Escena: visita de } \\
\text { soberanos ingleses a } \\
\text { París en } 1914\end{array}$ & París/Ambato & $\begin{array}{l}\text { Rita/Mercedes de } \\
\text { Ortega }\end{array}$ \\
\hline 84.F.19.157 & 24.04.1914 & $\begin{array}{l}\text { Souvenir de la } \\
\text { coronación del rey } \\
\text { Jorge V y Mary, } \\
\text { Reina de Inglaterra }\end{array}$ & París/Ambato & $\begin{array}{l}\text { Rita/Adelina de } \\
\text { Vásconez }\end{array}$ \\
\hline 84.F.19.158 & 28.08 .1914 & $\begin{array}{l}\text { París: plaza de la } \\
\text { Nación }\end{array}$ & París/Ambato & $\begin{array}{l}\text { Rita/Adelina de } \\
\text { Vásconez }\end{array}$ \\
\hline 84.F.19.159 & 23.04.1913 & $\begin{array}{l}\text { Lourdes: vista } \\
\text { general }\end{array}$ & Lourdes/Ambato & $\begin{array}{l}\text { Rita/Mercedes de } \\
\text { Ortega }\end{array}$ \\
\hline 84.F.19.160 & & Lourdes: la Basilique & & En blanco \\
\hline 84.F.19.161 & & $\begin{array}{l}\text { Fontainebleau: Acta } \\
\text { de abdicación de } \\
\text { Napoleón }\end{array}$ & & En blanco \\
\hline
\end{tabular}


Postales, viaje y turismo: la experiencia de una viajera ecuatoriana a inicios del siglo XX

\begin{tabular}{|c|c|c|c|c|}
\hline Código tarjeta & Fecha & Motivo & Origen/Destino & Remitente/destinatario \\
\hline 84.F.19.162 & & $\begin{array}{l}\text { Lourdes: vista de } \\
\text { paisaje con la basílica }\end{array}$ & & En blanco \\
\hline 84.F.19.163 & 08.01 .1912 & $\begin{array}{l}\text { Santiago: cerro Santa } \\
\text { Lucía }\end{array}$ & Santiago/Ambato & $\begin{array}{l}\text { Rita/Adelina de } \\
\text { Vásconez }\end{array}$ \\
\hline 84.F.19.164 & & $\begin{array}{l}\text { Retrato de Bernadette } \\
\text { Soubirous }\end{array}$ & & En blanco \\
\hline 84.F.19.165 & 19.03.1920 & $\begin{array}{l}\text { Conmemorativa: } \\
\text { reproducción de una } \\
\text { rosa roja }\end{array}$ & Sin dato & $\begin{array}{l}\text { Ángel Arias y Sra/ } \\
\text { Ernesto Vásconez }\end{array}$ \\
\hline 84.F.19.166 & & Lourdes: la Gruta & & En blanco \\
\hline 84.F.19.167 & & Lourdes: la Basilique & & En blanco \\
\hline 84.F.19.168 & & $\begin{array}{l}\text { Lourdes: Interior de } \\
\text { la cripta }\end{array}$ & & En blanco \\
\hline 84.F.19.169 & Sin fecha & Lourdes: la Basilique & $\begin{array}{l}\text { Posible } \\
\text { continuación de otra } \\
\text { tarjeta }\end{array}$ & Rita/no aparece \\
\hline 84.F.19.170 & 23.04 .1913 & $\begin{array}{l}\text { Lourdes: Gruta y } \\
\text { basílica }\end{array}$ & Lourdes/Ambato & $\begin{array}{l}\text { Rita/Ernesto } \\
\text { Vásconez }\end{array}$ \\
\hline 84.F.19.171 & & Lourdes: la Basilique & & En blanco \\
\hline 84.F.19.172 & & $\begin{array}{l}\text { Lourdes: La } \\
\text { Basilique y las } \\
\text { piscinas }\end{array}$ & & En blanco \\
\hline 84.F.19.173 & & $\begin{array}{l}\text { Lourdes: el fuerte del } \\
\text { castillo }\end{array}$ & & \\
\hline 84.F.19.174 & & $\begin{array}{l}\text { Lourdes: La } \\
\text { Basilique }\end{array}$ & & \\
\hline 84.F.19.175 & 18.04 .1913 & Montecarlo & Montecarlo/Ambato & $\begin{array}{l}\text { Rita/Adelina de } \\
\text { Vásconez }\end{array}$ \\
\hline 84.F.19.176 & 01.01 .1914 & $\begin{array}{l}\text { Conmemorativa: } \\
\text { pareja de niños } \\
\text { portando un gran } \\
\text { ramo de flores }\end{array}$ & París/Ambato & $\begin{array}{l}\text { Rita/Adelina de } \\
\text { Vásconez }\end{array}$ \\
\hline
\end{tabular}


María Ángela Cifuentes Guerra

\begin{tabular}{|c|c|c|c|c|}
\hline Código tarjeta & Fecha & Motivo & Origen/Destino & Remitente/destinatario \\
\hline 84.F.19.177 & 05.11 .1913 & $\begin{array}{l}\text { Enghien les Bains: } \\
\text { Panorama del jardín } \\
\text { del casino }\end{array}$ & París/Ambato & $\begin{array}{l}\text { Rita/Adelina de } \\
\text { Vásconez }\end{array}$ \\
\hline 84.F.19.178 & & $\begin{array}{l}\text { Niza: Promenade des } \\
\text { Anglais }\end{array}$ & & En blanco \\
\hline 84.F.19.179 & 02.07.1914 & $\begin{array}{l}\text { Conmemorativa: } \\
\text { retrato de joven }\end{array}$ & Sin dato/Ambato & $\begin{array}{l}\text { Rita/Adelina de } \\
\text { Vásconez }\end{array}$ \\
\hline 84.F.19.180 & 19.04.1913 & $\begin{array}{l}\text { Niza: Promenade des } \\
\text { Anglais }\end{array}$ & Niza/Ambato & $\begin{array}{l}\text { Rita/Mercedes de } \\
\text { Ortega }\end{array}$ \\
\hline 84.F.19.181 & 19.04.1913 & $\begin{array}{l}\text { Niza: Jardín público } \\
\text { y Casino Municipal }\end{array}$ & Niza/Ambato & $\begin{array}{l}\text { Rita/Ernesto } \\
\text { Vásconez }\end{array}$ \\
\hline 84.F.19.182 & 26.07.1913 & $\begin{array}{l}\text { Conmemorativa: } \\
\text { Niña con gran ramo } \\
\text { de flores }\end{array}$ & París/Ambato & $\begin{array}{l}\text { Rita/Adelina de } \\
\text { Vásconez }\end{array}$ \\
\hline 84.F.19.183 & 19.04.1913 & $\begin{array}{l}\text { Niza: Promenade des } \\
\text { Anglais }\end{array}$ & Niza/Ambato & $\begin{array}{l}\text { Rita/Adelina de } \\
\text { Vásconez }\end{array}$ \\
\hline 84.F.19.184 & & Vittel: Casino & & En blanco \\
\hline 84.F.19.185 & 22.07.1914 & Vittel: Las galerías & Vittel/Ambato & $\begin{array}{l}\text { Rita/Adelina de } \\
\text { Vásconez }\end{array}$ \\
\hline 84.F.19.186 & 09.07.1914 & $\begin{array}{l}\text { Vittel: visitantes en la } \\
\text { Grande Source }\end{array}$ & Vittel/Ambato & $\begin{array}{l}\text { Rita/Adelina de } \\
\text { Vásconez }\end{array}$ \\
\hline 84.F.19.187 & & $\begin{array}{l}\text { Vittel: Promenade de } \\
\text { galerías }\end{array}$ & & En blanco \\
\hline 84.F.19.188 & 28.07 .1914 & $\begin{array}{l}\text { Vittel: edificación de } \\
\text { hotel }\end{array}$ & Vittel/Ambato & $\begin{array}{l}\text { Rita/Adelina de } \\
\text { Vásconez }\end{array}$ \\
\hline 84.F.19.189 & 15.07.1914 & $\begin{array}{l}\text { Vittel: Escena en } \\
\text { parque }\end{array}$ & Vittel/Ambato & $\begin{array}{l}\text { Rita/Adelina de } \\
\text { Vásconez }\end{array}$ \\
\hline 84.F.19.190 & 23.07 .1914 & $\begin{array}{l}\text { Vittel: vista de } \\
\text { L'Esplanade }\end{array}$ & Vittel/Ambato & $\begin{array}{l}\text { Rita/Ernesto } \\
\text { Vásconez }\end{array}$ \\
\hline 84.F.19.191 & & $\begin{array}{l}\text { Vittel: visitantes en la } \\
\text { Grande Source }\end{array}$ & & En blanco \\
\hline 84.F.19.192 & 28.07.1914 & $\begin{array}{l}\text { Vittel: vista de las } \\
\text { Galerías }\end{array}$ & Vittel/Ambato & $\begin{array}{l}\text { Rita/Mercedes de } \\
\text { Ortega }\end{array}$ \\
\hline
\end{tabular}


Postales, viaje y turismo: la experiencia de una viajera ecuatoriana a inicios del siglo XX

\begin{tabular}{|c|c|c|c|c|}
\hline Código tarjeta & Fecha & Motivo & Origen/Destino & Remitente/destinatario \\
\hline 84.F.19.193 & & $\begin{array}{l}\text { Escena histórica: } \\
\text { despedida de } \\
\text { Napoleón a la } \\
\text { guardia imperial. } \\
\text { Fontainebleau }\end{array}$ & & En blanco \\
\hline 84.F.19.194 & 13.03 .1914 & $\begin{array}{l}\text { Conmemorativa: } \\
\text { Bonne Annèe. Joven } \\
\text { portando un ramo de } \\
\text { flores }\end{array}$ & París/Ambato & $\begin{array}{l}\text { Rita/Ernesto } \\
\text { Vásconez }\end{array}$ \\
\hline 84.F.19.195 & 04.03 .1913 & $\begin{array}{l}\text { Viena: escena de } \\
\text { parque de diversiones } \\
\text { con rueda moscovita } \\
\text { al fondo }\end{array}$ & Viena/Ambato & $\begin{array}{l}\text { Rita/Ernesto de } \\
\text { Vásconez }\end{array}$ \\
\hline 84.F.19.196 & & $\begin{array}{l}\text { Canal de Panamá: } \\
\text { vista de construcción }\end{array}$ & & En blanco \\
\hline 84.F.19.197 & & $\begin{array}{l}\text { Canal de Panamá: } \\
\text { vista de construcción } \\
\text { estructura }\end{array}$ & & En blanco \\
\hline 84.F.19.198 & & $\begin{array}{l}\text { Canal de Panamá: } \\
\text { Esclusa Pedro Miguel } \\
\text { en construcción }\end{array}$ & & En blanco \\
\hline 84.F.19.199 & & $\begin{array}{l}\text { Canal de Panamá: } \\
\text { Esclusa Pedro Miguel } \\
\text { en construcción }\end{array}$ & & En blanco \\
\hline Sin código & & $\begin{array}{l}\text { Canal de Panamá: } \\
\text { Esclusa Gatún }\end{array}$ & & En blanco \\
\hline 84.F.19.200 & & $\begin{array}{l}\text { Canal de Panamá: } \\
\text { Esclusas Gatún en } \\
\text { construcción }\end{array}$ & & En blanco \\
\hline 84.F.19.201 & & $\begin{array}{l}\text { Canal de Panamá: } \\
\text { Esclusas Gatún en } \\
\text { construcción }\end{array}$ & & En blanco \\
\hline 84.F.19.202 & & $\begin{array}{l}\text { Escena: dique en } \\
\text { Miraflores estallando } \\
\text { con } 20 \text { toneladas de } \\
\text { dinamita }\end{array}$ & & En blanco \\
\hline
\end{tabular}


María Ángela Cifuentes Guerra

\begin{tabular}{|c|c|c|c|c|}
\hline Código tarjeta & Fecha & Motivo & Origen/Destino & Remitente/destinatario \\
\hline 84.F.19.203 & & $\begin{array}{l}\text { Canal de Panamá: vista } \\
\text { a esclusa Pedro Miguel } \\
\text { en construcción }\end{array}$ & & En blanco \\
\hline 84.F.19.204 & & $\begin{array}{l}\text { Canal de Panamá: } \\
\text { esclusa }\end{array}$ & & En blanco \\
\hline 84.F.19.205 & & $\begin{array}{l}\text { Paisaje marítimo: } \\
\text { Canal desde el dique }\end{array}$ & & En blanco \\
\hline 84.F.19.206 & & $\begin{array}{l}\text { Paisaje marítimo: en } \\
\text { rompeolas Balboa }\end{array}$ & & En blanco \\
\hline 84.F.19.207 & 05.07 .1918 & $\begin{array}{l}\text { N.Y.: Estación } \\
\text { Pennsylvania }\end{array}$ & N.Y./Ambato & $\begin{array}{l}\text { R. Villacrés/Adelina } \\
\text { de Vásconez }\end{array}$ \\
\hline 84.F.19.208 & 26.07.1914 & $\begin{array}{l}\text { Conmemorativa: } \\
\text { canasto con flores }\end{array}$ & Vittel/Ambato & $\begin{array}{l}\text { Rita/Adelina de } \\
\text { Vásconez }\end{array}$ \\
\hline 84.F.19.209 & Sin fecha & $\begin{array}{l}\text { Edificación de } \\
\text { Universidad de } \\
\text { Pennsylvania }\end{array}$ & Sin dato & $\begin{array}{l}\text { Sin destinatario. } \\
\text { Texto de descripción } \\
\text { de la universidad } \\
\text { donde la persona } \\
\text { estudió. Sin firma }\end{array}$ \\
\hline 84.F.19.210 & Sin fecha & $\begin{array}{l}\text { Filadelfia: Hall } \\
\text { horticultural, } \\
\text { Fairmount Park }\end{array}$ & Sin dato & $\begin{array}{l}\text { Sin destinatario. } \\
\text { Descripción corta del } \\
\text { parque }\end{array}$ \\
\hline 84.F.19.211 & 12.04.1914 & $\begin{array}{l}\text { Conmemorativa: } \\
\text { figuras de mujeres: } \\
\text { siluetas parisinas }\end{array}$ & París/Ambato & $\begin{array}{l}\text { Rita/Adelina de } \\
\text { Vásconez }\end{array}$ \\
\hline 84.F.19.212 & Sin fecha & $\begin{array}{l}\text { Filadelfia: } \\
\text { Metropolitan Opera } \\
\text { House }\end{array}$ & Sin dato & $\begin{array}{l}\text { Sin destinatario: } \\
\text { descripción corta de } \\
\text { La Ópera. }\end{array}$ \\
\hline 84.F.19.213 & & $\begin{array}{l}\text { Pavia: versión } \\
\text { escultórica de } L a \\
\text { Pietá }\end{array}$ & & En blanco \\
\hline 84.F.19.214 & Sin fecha & Filadelfia: Navy Yard & Sin dato & $\begin{array}{l}\text { Sin destinatario: } \\
\text { señala que imagen es } \\
\text { de buque de guerra }\end{array}$ \\
\hline 84.F.19.215 & 16.05 .1914 & $\begin{array}{l}\text { Ilustración del } \\
\text { Transatlantique } \\
\text { (french line) }\end{array}$ & N.Y./Ambato & $\begin{array}{l}\text { Ángel/Adelina de } \\
\text { Vásconez }\end{array}$ \\
\hline
\end{tabular}

